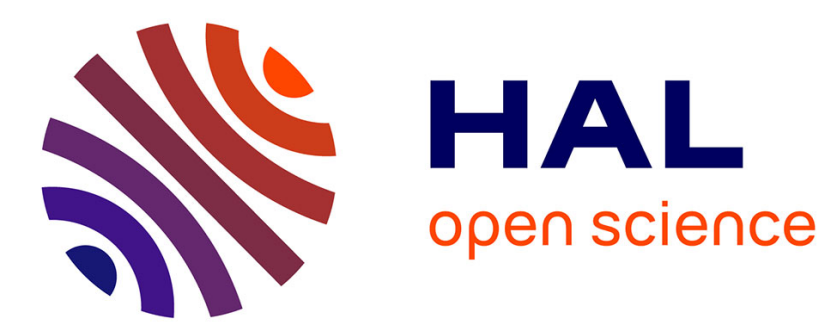

\title{
Marine aerosol distribution and variability over the pristine Southern Indian Ocean
}

Paul-Etienne Mallet, Olivier Pujol, Jérôme Brioude, Stéphanie Evan, Andrew Jensen

\section{- To cite this version:}

Paul-Etienne Mallet, Olivier Pujol, Jérôme Brioude, Stéphanie Evan, Andrew Jensen. Marine aerosol distribution and variability over the pristine Southern Indian Ocean. Atmospheric Environment, 2018, 182, pp.17-30. 10.1016/j.atmosenv.2018.03.016 . hal-01740819

\section{HAL Id: hal-01740819 \\ https://hal.science/hal-01740819}

Submitted on 22 Mar 2018

HAL is a multi-disciplinary open access archive for the deposit and dissemination of scientific research documents, whether they are published or not. The documents may come from teaching and research institutions in France or abroad, or from public or private research centers.
L'archive ouverte pluridisciplinaire HAL, est destinée au dépôt et à la diffusion de documents scientifiques de niveau recherche, publiés ou non, émanant des établissements d'enseignement et de recherche français ou étrangers, des laboratoires publics ou privés. 


\title{
Marine aerosol distribution and variability over the pristine Southern Indian Ocean
}

\author{
Paul-Étienne Mallet ${ }^{\mathrm{a}}$, Olivier Pujol ${ }^{\mathrm{a}, *}$, Jérôme Brioude $^{\mathrm{b}}$, Stéphanie Évan ${ }^{\mathrm{b}}$, \\ Andrew David Jensen ${ }^{c}$ \\ ${ }^{a}$ Université de Lille, Département de Physique, Laboratoire d'Optique Atmosphérique, \\ 59655, Villeneuve d'Ascq, France \\ ${ }^{b}$ Laboratoire de l'Atmosphère et des Cyclones, UMR 8105, Météo-France/CNRS/Université \\ de La Réunion, Saint-Denis de la Réunion, France \\ ${ }^{c}$ Mathematical Sciences, Northland College, Ashland, 54806, WI, USA
}

\begin{abstract}
This paper presents an 8-year (2005-2012 inclusive) study of the marine aerosol distribution and variability over the Southern Indian Ocean, precisely in the area $\left\{10^{\circ} \mathrm{S}-40^{\circ} \mathrm{S} ; 50^{\circ} \mathrm{E}-110^{\circ} \mathrm{E}\right\}$ which has been identified as one of the most pristine regions of the globe. A large dataset made of satellite data (POLDER, CALIOP), AERONET measurements at Saint-Denis (French Reunion Island) and model reanalysis (MACC), has been used. In spite of a positive bias of about 0.05 between the AOD (aerosol optical depth) given by POLDER and MACC on one hand and the AOD measured by AERONET on the other hand, consistent results about the aerosol distribution and variability over the area considered have been obtained. First, aerosols are mainly confined below $2 \mathrm{~km}$ asl (above sea level) and are dominated by sea salt, especially in the center of the area of interest, with $A O D \lesssim 0.1$. This zone is the most pristine and is associated to the Mascarene anticyclone position. There, the direct radiative effect is assessed around $-9 \mathrm{~W} \mathrm{~m}^{-2}$ at TOA (top of the atmosphere) and probability density functions of the $A O D$ s are leptokurtic lognormal functions without

*. Corresponding author

Email addresses: paul-etienne.mallet@univ-lille1.fr (Paul-Étienne Mallet), olivier.pujol@univ-lille1.fr (Olivier Pujol), jerome.brioude@univ-reunion.fr (Jérôme Brioude), stephanie.evan@univ-reunion.fr (Stéphanie Évan), ajensen@northland.edu (Andrew David Jensen)
\end{abstract}


any significant seasonal variation. It is also suggested that the Madden-Jullian oscillation (MJO) impacts sea salt emissions in the northern part of the area considered by modifying the Reynold number of the sea surface. Finally, this area is surrounded in the northeast and the southwest by seasonal Australian and South African intrusions $(A O D>0.1)$; all along the year, the ITCZ seems to limit continental contaminations from Asia. Due to the long period of time considered (almost a decade), this paper strenghens some observations performed during previous field campaigns and completes them by showing monthly the variability of the marine aerosols in the Southern Indian Ocean.

Keywords: Sea spray aerosols, marine $A O D$, pristine conditions, Southern Indian Ocean

\section{Introduction}

Oceans cover about $70 \%$ of the Earth surface and thus sea-air interactions play a key role in the atmospheric system, from local to global scales. In particular, oceans are a reservoir of sea spray aerosols, i.e. sea salt aerosols (SSA) and

5 primary organic matter (e. g. chlorophyll- $a$, see Gantt and Meskhidze (2013), and are thus the most widely distributed natural aerosols (average total flux sea spray is $4100 \mathrm{Tg} \mathrm{yr}^{-1}$ according to (IPCC, 2013, p. 596)). Oceans also produce sulfate from DMS 1 . SSA consist of seawater drops and dry sea salt particles (ionic species, as sodium, potassium, ...) whose sizes can extend from $0.05 \mu \mathrm{m}$ up to $1 \mathrm{~mm}$ (e. g. O'Dowd et al. 1997). They are produced at the sea surface by various mechanical processes (Woodcock, 1948, Boyce, 1951, 1954, Blanchard, 1963. Monahan et al. 1986). For detailed information about SSA physical and chemical properties, as well as their mechanism of production, see Lewis and Schwartz (2004, and the exhaustive reference list therein). These natural aero-

15 sols are of fundamental importance for climate and interrelated topics (IPCC, 2013): direct and indirect radiative forcing, cloud formation and lifetime, atmos-

1. Dimethylsulfide 
pheric electrical charge (e. g. Blanchard, 1985), possibly hurricane development (Emanuel, 2003), chemical cycles and health. Marine environments can also be influenced by continental emissions and can contain other kinds of both natural and anthropogenic aerosols (Prospero et al. 2002) like dusts and minerals, biological matter, sulfate, nitrate, and organic aerosols (e. g. soot, carbonaceous material). Considered together, all of the aerosols in marine environments are referred as 'marine aerosols', (see O’Dowd and de Leeuw, 2007, Fitzgerald, 1991)). In pristine regions, i. e. undisturbed marine environments, where land and human activities have little impact, SSA are dominant (50\% to $70 \%$ of the aerosol mass, IPCC (2013, p. 596)). Such regions are interesting for at least two reasons: (1) they can be considered as good indicators of the meteorological conditions during the preindustrial epoch, which is a crucial point to better quantify the contribution of natural emissions to the changing climate. (2) Aerosol concentrations are relatively low and so changes in the aerosol concentration can give rise to unexpected results. E. g., Koren et al. (2014) suggested that small modifications in the SSA concentration may have a large effect on clouds and on the climate by favoring warm convective cloud invigoration. Pristine regions are located mainly in the Southern Hemisphere (e.g. Hamilton et al., 2014), i.e. 35 the Southern Indian Ocean, the South Pacific, and the South Atlantic between Brazil and South Africa.

The focus here is on the vast region of the Southern Indian Ocean located specifically between $10^{\circ} \mathrm{S}$ to $40^{\circ} \mathrm{S}$ latitude and $50^{\circ} \mathrm{E}$ to $110^{\circ} \mathrm{E}$ longitude. To the authors' knowledge, this area has not been examined as comprehensively as others in the Pacific, Atlantic, or in other seas, although it is often included in global analyses of SSA characteristics and properties (e. g. Jaeglé et al., 2011).

Some studies have already been devoted to aerosols over the Indian Ocean, especially its northest part, around India, and have addressed the impact of anthropogenic and land contaminations from Asia on the marine background. 45 In particular, these studies have exploited data collected during the INDOEX ${ }^{2}$

2. Indian Ocean Experiment 
(see http://www-indoex.ucsd.edu/ and references therein for details) from January to March, in 1998 and 1999, and aimed at understanding the transport of continental aerosols to pristine ocean and their radiative impact. Both observations and models have revealed an abrupt transition, close to the ITCZ 3 between the northest and the southest air masses, which has been called the "Chemical ITCZ" Lawrence et al. 2003) or the "Chemical equator" Hamilton et al., 2008, here for the Western Pacific). E.g., from shipborne measurments, Moorthy et al. (1999) have noticed, across the ITCZ, a sharp negative southward $A O D$ gradient at shorwaves and no longwave $A O D$ variation, suggesting large aerosols of oceanic origin south of the ITCZ, and Norman et al. (2003) have shown strong decreasing (by a factor up to 40) in the concentrations of anthropogenic and continental sources of submicrometer aerosols. Also, during the 1999 intensive field phase of INDOEX, Welton et al. (2002) have measured $A O D$ (at $523 \mathrm{~nm}$ ) of $0.05 \pm 0.03$ for marine aerosols in the absence of any continental influence with a peak extinction close to the top of the MBL 4 . In addition, Rajeev et al. (2000) have studied the aerosol distribution through AVHRR observation during February-March 1998: AOD at $630 \mathrm{~nm}$ appears smaller than 0.1 in the Southern Hemisphere Indian Ocean, but the non-SSA component is estimated to exceed the SSA component because of interhemispheric transport, 65 despite the high SSA production associated with high wind speed values around $20^{\circ} \mathrm{S}$. Atmospheric models have also been used to describe shortwave $A O D$ and aerosol radiative forcing from January to March 1999 (e. g. Rasch et al., 2001, Collins et al., 2002, Reddy et al. 2004). It has been obtained $A O D$ values lower than 0.1 from 10 to $30^{\circ} \mathrm{S}$, with larger values due to Australian dust and SSA contribution to total $A O D$ around $40-60 \%$. Other studies after the INDOEX have analyzed the impact of Asia contamination to the Southern Indian Ocean (e. g. Pant et al., 2009); Lawrence and Lelieveld (2010) have proposed a review of the knowledge about the southern Asian pollutant outflow (see especially

3. Inter Tropical Convergence Zone

4. Marine Boundary Layer 
sections 4 and 6 in this reference for the Indian Ocean) and have encouraged further studies all along the year.

As indicated, the studies mentioned above have focused on relative short periods of time (at most three months) and which is almost always the same (the winter moonson season). In this paper, we present a 8-year (2005-2012 inclusive) study of the $A O D$ and aerosol distribution and variability (throughout a year) in the pristine area indicated above. To the authors knowledge, none study over almost a decade have yet been performed over the pristine Indian Ocean region. To that end, several sources of independent data have been used: spaceborne instruments, ground stations, and model reanalysis. A short description of each is given in Section 2. The period chosen (2005-2012) corresponds to 85 that for which all of these sources of data were available together. The spatial distributions and variabilities of the $A O D$ and aerosols are presented in Section 3. In Section 4 probability density functions (pdfs) related to $A O D$ are computed. The pdfs may be of interest to aerosol/cloud modeling research since they can provide a statistical basis for theoretical analysis and inform numerical models. These results are then used (Section 5 to assess the direct radiative effect of aerosols (DREA) at the top of the atmosphere (TOA). Finally, conclusions are given in Section 6 .

\section{Description of datasets and intercomparisons}

\subsection{Satellite data}

Spaceborne instruments are used to measure the aerosol optical depth $(A O D)$ at regional and synoptic scales. The $A O D$ data comes from retrievals from the POLDER-3/PARASOL instrument 5 onboard a CNES/Myriade microsatellite, launched in December 2004 within the A-train constellation. POLDER is a wide field of view imaging radiometer which provides measurements of the spectral, polarized and directionality of solar radiation reflected by aerosols and clouds.

5. Polarisation and directionality of the Earth's Reflectances/ Polarization and Anisotropy of Reflectances for Atmospheric science coupled with Observation from a Lidar 
Among the Level 2 products, the aerosol optical thickness data correspond physically to $A O D$ at a wavelength (in vacuum) $\lambda=865 \mathrm{~nm}$. This product is available from March 2005 to October 2013 with a latitude/longitude (lat/lon) resolution of $1 / 6^{\circ} \times 1 / 6^{\circ}$. In the present study, this product has been averaged on a daily $0.75^{\circ} \times 0.75^{\circ}$ lat/lon grid, in order to have the same gridding as other data fields for comparisons described further below. This change does not modify substantially the number $\left(10^{6}\right)$ of data points over the area considered. This number is high enough to allow the statistical examination to be further presented throughout this paper. Over oceans, surface reflectance is an important source of uncertainty in aerosol remote sensing, but cloud screening is probably the largest one (Myhre et al., 2004, and references therein). The POLDER cloud screening identification procedure is based on reflectance threshold values, pressure and polarization considerations (e. g. Bréon and Colzy, 1999 , for details). Overall, the uncertainty in the $A O D$ provided in the Level 2 product is about 0.02 over the area of investigation.

In addition to POLDER data, we have also used data from the spacelidar CALIOP/CALIPSO 6 to examine how aerosols are distributed along the vertical. This instrument provides backscattering profiles at $\lambda=532 \mathrm{~nm}$ and $1064 \mathrm{~nm}$, including parallel and perpendicular polarized signals at $532 \mathrm{~nm}$. Precisely, we used the Level 3 product associated with monthly averaged aerosol extinction profiles at $532 \mathrm{~nm}$ over a uniform spatial grid $\left(2^{\circ} \times 5^{\circ}\right.$ lat/lon $)$ with a vertical resolution of $30 \mathrm{~m}(60 \mathrm{~m}$ above $8.2 \mathrm{~km}$ ) (Winker et al., 2010). In this Level 3 product, cloudy pixels are removed after calibration and range registration to avoid cloud contamination of the aerosol data. See (Liu et al. 2000, 2004) for the aerosol-cloud discrimination technique.

6. Cloud-Aerosol Lidar with Orthogonal Polarization / Cloud-Aerosol Lidar and Infra-red Pathfinder Satellite Observation 


\subsection{Ground Data: Aeronet/Aeroman}

AERONET 7 (Holben et al. 1998, 2001) is an international collaborative network of ground-based CIMEL Sun-Photometers providing high quality aerosol optical property observations over the long term. The AERONET dataset is are pre- and post-field calibrated, cloud-screened, and quality-assured (Dubovik and King, 2000, Dubovik et al. 2002), have been used. Data are ranked by observation time, with a temporal resolution of around 15 min under cloud-free conditions. Daily-averaged data are also available. The estimated uncertainty in AOD measurements is about $0.01-0.02$.

There are two AERONET stations over the Southern Indian Ocean: one located at Saint-Denis on the French Réunion Island $\left(20.883^{\circ} \mathrm{S}, 55.483^{\circ} \mathrm{E}\right)$ and the other one at Amsterdam Island $\left(37.810^{\circ} \mathrm{S}, 77.573^{\circ} \mathrm{E}\right)$. In order to increase the spatial coverage of the examined area, we have also used the Maritime Aerosol Network (MAN or Aeroman) (Smirnov et al. 2009), which provides shipborne $A O D$ measurements from the Microtops II sun photometers with an estimated uncertainty not exceeding 0.02. A total of 19 missions have been conducted over the Southern Indian Ocean between the years 2007 and 2013. Among all of these data, the Reunion Island AERONET station represents a

\subsection{Reanalysis}

Meteorological reanalyses are of considerable interest for our purposes since they provide an estimate of the thermodynamic state and composition of the atmosphere (and/or ocean), even for areas not covered by observations for various reasons (absence of stations, cloud cover masking low atmospheric levels, etc.). Reanalysis consists in the assimilation of observations (from e. g. satellite instruments, weather stations, ships, buoys, etc.) into atmospheric models in order to determine as best as possible the atmospheric state.

7. Aerosol Robotic NETwork 
Herein, the thermodynamic variables representing the meteorological condiaerosols (organic matter, black carbon, and sulfate) are deduced from monthly

8. Monitoring Atmospheric Composition and Climate - Interim Implementation; ECMWF 
and annual mean climatologies. Data are represented on a $0.75^{\circ} \times 0.75^{\circ}$ lat $/$ lon grid over 60 vertical levels from surface to $0.1 \mathrm{hPa}$ (about $70 \mathrm{~km}$ ). We note that POLDER observations are not assimilated in MACC (it assimilates MODIS observations), thus both datasets are independent. To facilitate dataset intercomparisons, the period of study is limited to January 2005 to December 2012.

\subsection{AOD intercomparison}

In this subsection, the POLDER-retrieved AODs and those from MACC outputs are compared with Aeronet/Aeroman measurements in order to determine whether they provide realistic $A O D$ s. Indeed, AERONET $A O D$ measurements are recognized to be of quality. They have smaller uncertainties than satellite observations, which are often impacted by surface optical properties (reflectance and emissivity) and depend on a radiative transfer scheme. The intercomparison of $A O D$ s requires that the POLDER and MACC $A O D$ s be collocated in the vicinity of the ground instrument. Precisely, an AERONET AOD measurement is considered if it falls into the pixel of POLDER and MACC. Moreover, since $A O D$ measurements are wavelength-dependent, the Aeronet/Aeroman $A O D \mathrm{~s}$ (at $\lambda=870 \mathrm{~nm}$ ) are interpolated to the wavelengths of POLDER $\left(\lambda_{1}=865 \mathrm{~nm}\right.$ ) and MACC $\left(\lambda_{2}=550 \mathrm{~nm}\right)$ through the Angstrom equation:

$$
\frac{A O D_{1}}{A O D_{2}}=\left(\frac{\lambda_{1}}{\lambda_{2}}\right)^{-\alpha}
$$

where $A O D_{i}(i=1,2)$ is the $A O D$ at $\lambda_{i}$ and $\alpha$ is the Angstrom exponent (Ångström, 1929). This is given by Aeronet/Aeroman. Overall, the values of $\alpha$ range from about 0.0 to 1.5 , with a mean of 0.7 . Such values are typical of marine aerosols. For instance, Smirnov et al. (2002) have reported values of $\alpha$ ranging from 0.3 to 0.7 over clean marine regions free of continental influences.

Figure 1 1a displays time series from 2007 to 2012 inclusive of the averaged $A O D$ s at $865 \mathrm{~nm}$ at Reunion Island. Average values were computed with a moving mean of 15 days after and 15 days before the considered date. There are no records for the period 2005-2007 for this AERONET station. The two series 
present some similarities, especially in the orders of magnitude and in the evolution of the averaged $A O D$, although POLDER slightly overestimates the $A O D \mathrm{~s}$ by about 0.05 on average. Agreement is better after 2010, although, according to the authors knowledge, no technical change occurred for the sun-photometer nor in the algorithm to process data. A comparison between the AERONET and POLDER monthly-averaged $A O D$ s (resp. $A O D_{A}$ and $A O D_{P}$ ) is presented on Figure 1 $\mathrm{b}$. The fitting equation obtained is $A O D_{P}=0.341 A O D_{A}+0.055$.

205 According to Chen et al. (2015) (and references 28, 29, and 30 therein), a nonzero intercept may be due to errors in calibration or surface reflectance while a non-unity slope may be associated to computation of the optical properties by the retrieval algorithm. In addition, the bias (difference of the mean values between the satellite products and the AERONET measurements) is 0.011 and 210 the root mean square error is $R M S E=0.027$. 


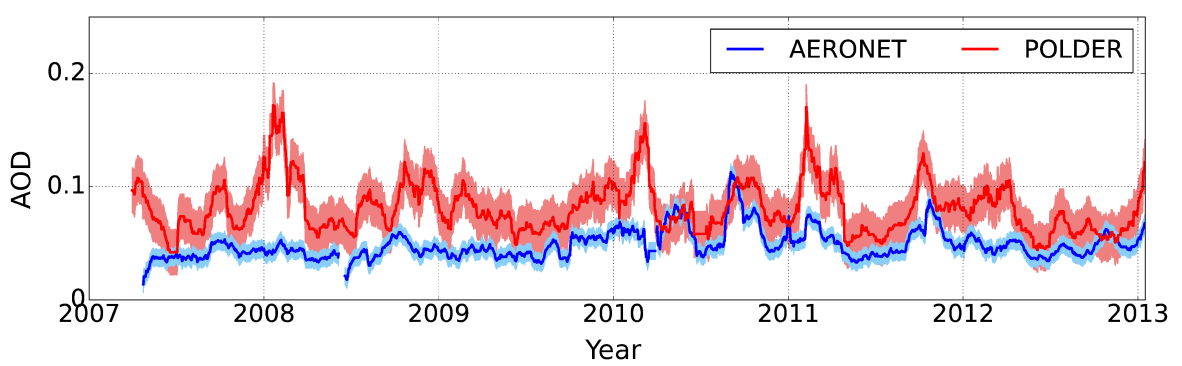

a)

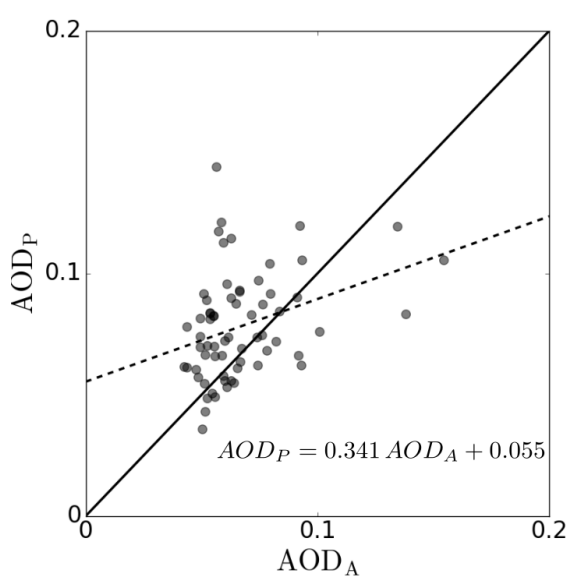

b)

FIG. 1 - (a) Time series (from 2007 to 2012 inclusive) of the monthly averaged AOD at $865 \mathrm{~nm}$ around the Reunion Island from POLDER retrieval (in red) and AERONET station (in blue). Each shaded area around each solid line represents uncertainties. (b) Scatterplot between AERONET and POLDER monthly-averaged AODs at $865 \mathrm{~nm}$ from 2007 to 2012 (inclusive). The fitting curve (dotted line) is $A O D_{P}=0.341 A O D_{A}+0.055$ with a correlation factor $r=0.34$.

Figure 2 a displays the comparison from 2007 to 2012 between the monthly averaged $A O D \mathrm{~s}$ (at $550 \mathrm{~nm}$ ) by MACC and those of the Reunion Island AERONET station. MACC overestimates the monthly $A O D$ s (mean $A O D$ value is 0.148 for MACC and 0.068 for AERONET), but represents better the temporal variations of the monthly $A O D$ than POLDER. In particular, we note that some peaks (ends of 2007, 2008, 2009, 2010, 2011, 2012) are quite well represented (though not in magnitude). We have not found any information about the 
uncertainties in the MACC AOD outputs. The scatterplot of the AERONET and MACC monthly-averaged $A O D \mathrm{~s}$ (resp. $A O D_{A}$ and $A O D_{M}$ ) is presented in Figure $2 \mathrm{~b}$. The fitting equation obtained is $A O D_{M}=1.081 A O D_{A}+0.076$. The slope is close to 1 but the intercept is not 0 , which means a systematic overestimation by MACC over the AERONET data. The correlation coefficient, the bias, and the $R M S E$ are respectively $0.79,0.082$ and 0.084 .

These long time series are consistent with the $A O D$ values obtained for short periods of time by other studies Rasch et al. (2001); Welton et al. (2002); Collins et al. (2002). 


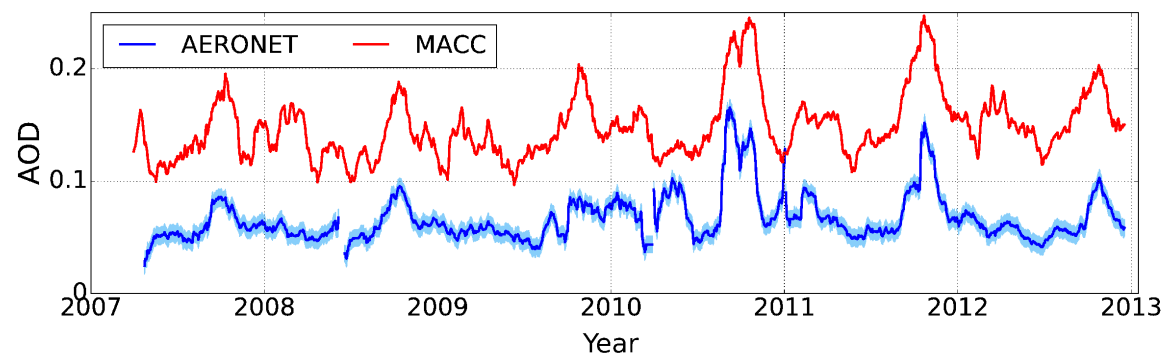

a)

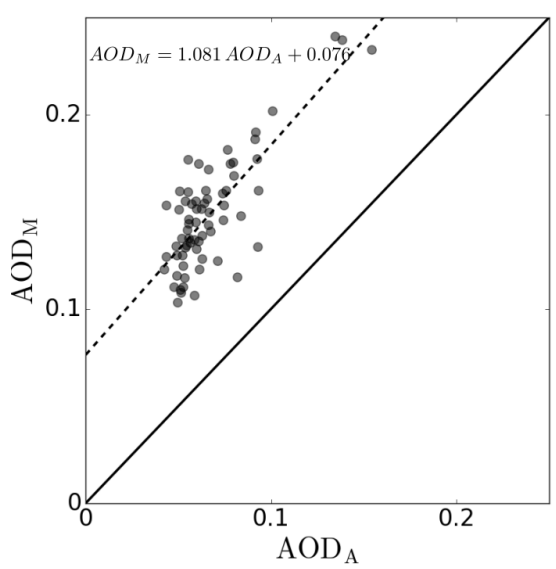

b)

FIG. 2 - (a) Time series (from 2007 to 2012 inclusive) of the monthly averaged AOD at $550 \mathrm{~nm}$ around the Reunion Island from MACC outputs (in red) and AERONET station (in blue). Each shaded area around each solid line represents uncertainties. (b) Scatterplot between AERONET and MACC daily AODs from 2007 to 2012 (included). The fitting curve (dotted line) is $A O D_{P}=1.081 A O D_{A}+0.076$ with a correlation factor $r=0.79$.

\section{Aerosol spatial distributions and variability}

\subsection{AOD horizontal field}

Figure 3 displays the mean POLDER AOD between 2005 and 2012 (inclusive). The Indian Basin clearly exhibits a meridional $A O D$ gradient with very low values $(A O D<0.15)$ in the Southern Hemisphere and higher values in the Northern Hemisphere close to the Arabian and Asian coasts. These higher 
values are due to anthropogenic and terrestrial emissions (e. g. Li and Ramanathan, 2002). In addition, recurrent high cloud cover south to $40^{\circ} \mathrm{S}$ prohibits focus is put on the marine area $\left\{10^{\circ} \mathrm{S}-40^{\circ} \mathrm{S} ; 50^{\circ} \mathrm{E}-110^{\circ} \mathrm{E}\right\}$ (white rectangle in Fig. 3), i. e. far from continental influences.

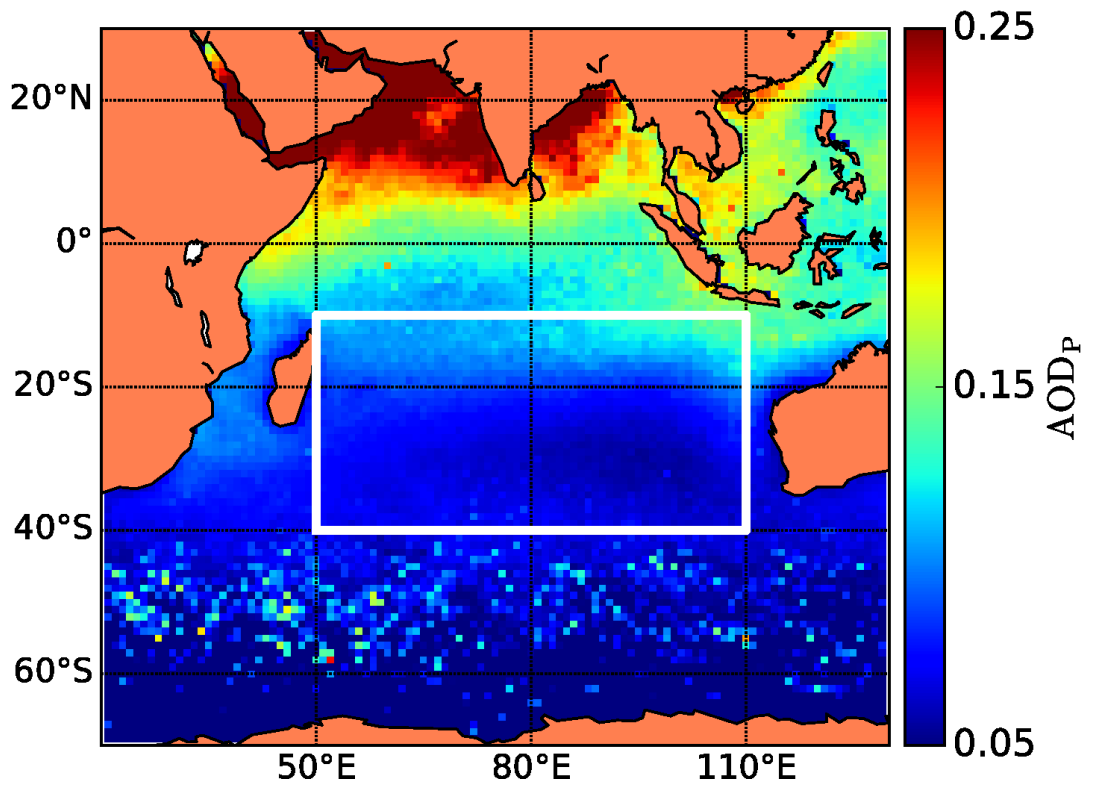

Fig. 3 - Mean POLDER AOD between 2005 and 2012 (inclusive). The rectangle with white border lines indicates the area under investigation.

\subsubsection{Monthly averaged AODs}

The horizontal field of the monthly averaged POLDER $A O D$ values $\left(\overline{A O D}_{P}\right)$ is displayed in Figure 4. These averages are based on at least $10^{3}$ number of grid points per month. Over the considered area, $\overline{A O D}_{P}<0.2$, especially in the southern part where $\overline{A O D}_{P}<0.13$. The $\overline{A O D}_{P}$ spatial distribution presents a striking north-south seasonal modulation. In January, February, and March (Fig. 4 a, b, c resp.), low $A O D$ values (in the south, $\overline{A O D}_{P}<0.1$ ) are separa245 ted from high $A O D$ values (in the north, $\overline{A O D}_{P}>0.1$ ) at $25^{\circ} \mathrm{S}$. This strong 
latitudinal $\overline{A O D}_{P}$ gradient starts moving northward in April (Fig. $4 \mathrm{~d}$ ) to reach a northernmost location in July and August (Fig. 4s, h). Then a southward motion begins in September (Fig. 4 ) and an $\overline{A O D}_{P}$ distribution similar to that of January is obtained in October, November and December (Fig. 4, k, 1 resp.). This separation between high and low $\overline{A O D}_{P}$ values presents a wavelike pattern in December and from January to April, reaching a southernmost position in the western part $\left(35^{\circ} \mathrm{S}\right)$ of the area; in the eastern part, position is around $25^{\circ} \mathrm{S}$.

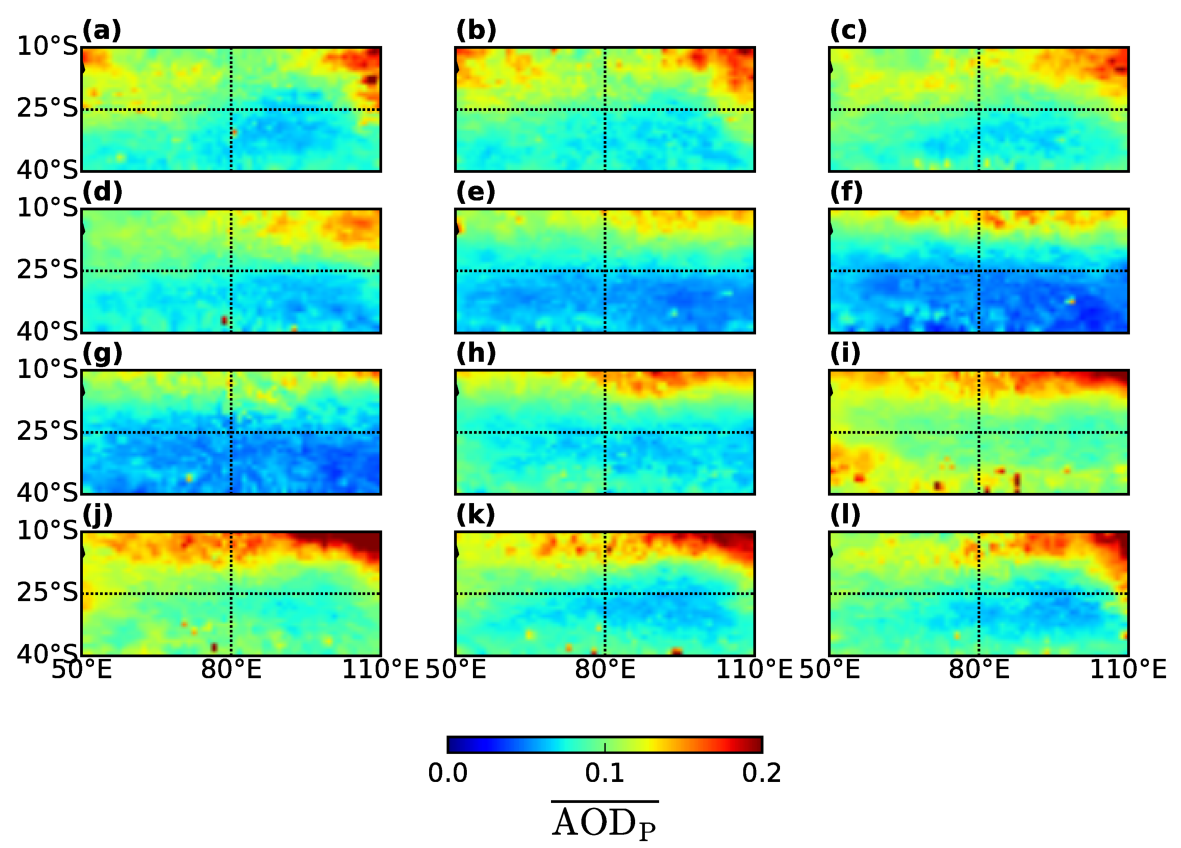

Fig. 4 - Horizontal field of the monthly averaged (from 2005 to 2012 inclusive) POLDER $A O D\left(\overline{A O D_{P}}\right)$, from January (a) to December (l).

This behaviour strongly suggests the ITCZ (Inter Tropical Convergence Zone) pattern and its south/north seasonal oscillation. Figure 5 sketches the position of the ITCZ in the Indian Ocean. In January, the ITCZ is centered around $5^{\circ} \mathrm{S}-10^{\circ} \mathrm{S}$, covering the northern part of the area considered and reaching a southernmost position west to $80^{\circ} \mathrm{E}$, while in July it passes much far- 
ther to the north, over India. By reducing interhemispheric air mass exchanges and washing out aerosols because of heavy precipitations associated to strong convection, the ITCZ can explain why the southern Indian Ocean is not greatly contaminated by northern continental emissions. This role has been noted for the winter moonson season by previous studies (see Introduction and (Lawrence and Lelieveld, 2010, section 4.2.2)) and similarly in the Western Pacific (Hamilton et al. 2008). It seems, from Fig. 4, that this natural protection also occurs for the rest of the year. On the other hand, at higher south latitudes, the descending branch of the Hadley cell, characterized by near-surface divergent flow and high pressure, corresponds to the Mascarenes anticyclone. It is centered near $30^{\circ} \mathrm{S}$ and extends from the Mascarenes Islands to the western coasts of Australia (i. e. between $60^{\circ} \mathrm{E}$ and $100^{\circ} \mathrm{E}$ ). The qualitative location of this anticyclone is also indicated in Figure 5. The position of this anticyclone appears to correspond to the lowest $\overline{A O D}_{P}$ values. The northeasternmost part of the area is characterized by $\overline{A O D}_{P}$ values greater than 0.2 from January to March (Fig. 4 a-c) and then from September to December (Fig. 4l-1). These relatively high values are likely due to the proximity of Australia and the prevailing easterly winds.

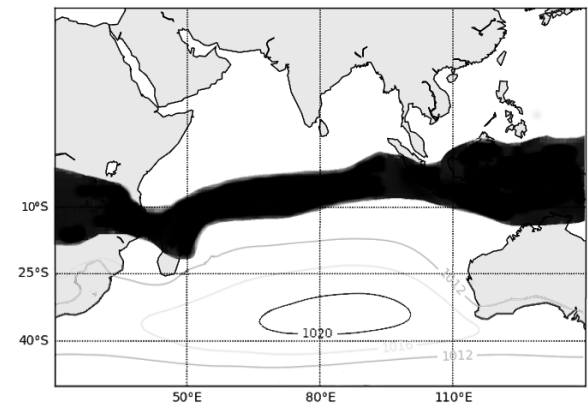

a)

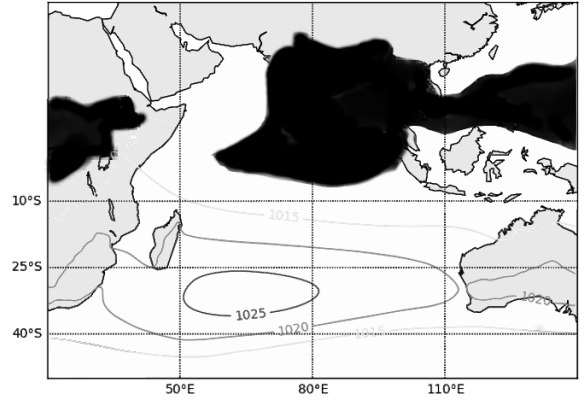

b)

FIG. 5 - Sketch of the ITCZ position in (a) January and (b) July. Isobar line in each subfigure indicate the position of the Mascarenes anticyclone. Sketch has been made using air vertical velocity from ECMWF. 
Figure 6 displays the horizontal field of the monthly averaged $A O D$ values computed from MACC $\left(\overline{A O D}_{M}\right)$. This represents the total aerosol burden. This field shows the same spatial organization and the same seasonal variability as the POLDER observed field $\left(\overline{A O D}_{P}\right)$. However, the values of $\overline{A O D}_{M}$ are overall slightly higher than those of $\overline{A O D}_{P}$ : precisely, $\overline{A O D}_{M} \approx 0.1-0.3$ while $\overline{A O D}_{P} \approx 0.02-0.2$. A similar overestimation has already been observed locally when comparing $A O D$ time series of MACC outputs with those of AERONET measurements.

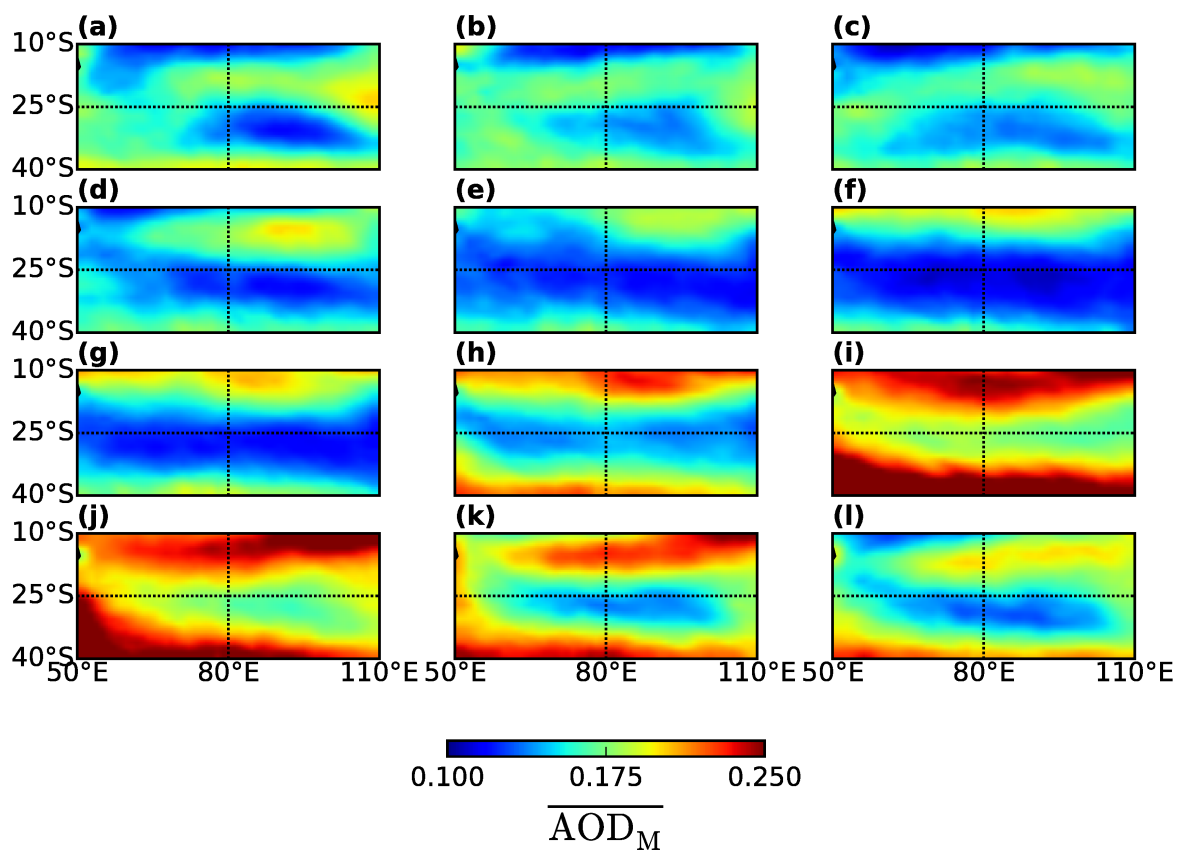

FIG. 6 - Horizontal field of the monthly averaged (from 2005 to 2012 inclusive) MACC AOD $\left(\overline{A O D_{M}}\right)$, from January (a) to December (l).

\subsection{Distribution of $M A C C$ aerosol species}

Figure 7 displays the annual average, over the period 2007-2012 (inclusive), of the horizontal $A O D$ fields of each of the five aerosol species (SSA, sulfate, organic matter, dust, and carbonic aerosols) as given by MACC. The following can be noted: (1) SSA is the dominant aerosol species; (2) there is no significant 
trace of black carbon aerosols; (3) sulfate aerosols have very low $A O D$ (about 0.04 at most) and are mainly located on the southern part of the area; (4) dust appear in the northeastern part of the area, close to the Australian coast; (5) organic matter is relatively uniformly distributed over the area with very low $A O D$ values (0.02 on average).

295

By considering each month separately (not shown), it can be seen that dust is mainly observed from August to March $(A O D \approx 0.04)$ with a peak in January $(A O D \approx 0.08)$ while organic matter can be observed in September and October $(A O D \approx 0.07)$ in the southwestern part of the area close to the South African coast. This is consistent with the knowledge about some aerosol sources: 300 Prospero et al. (2002) have reported dust emissions from Australia during the dry-season with a maximum in December-February; Barbosa et al. (1999) have noted biomass burning occurrences in southeast Africa during September and October; Menon et al. (2015) have observed, from December 2011 to February 2012 , very weak contribution of organic matter and sulfate aerosol sources north to $38^{\circ} \mathrm{S}$.

It will be shown thereafter that the low level wind circulation can explain such distributions. SSA represents around $60 \%$ of the total $A O D$ over the studied area, the maximum contribution being reached in June and July. On the center of the area, the maximum contribution is $80 \%$. 


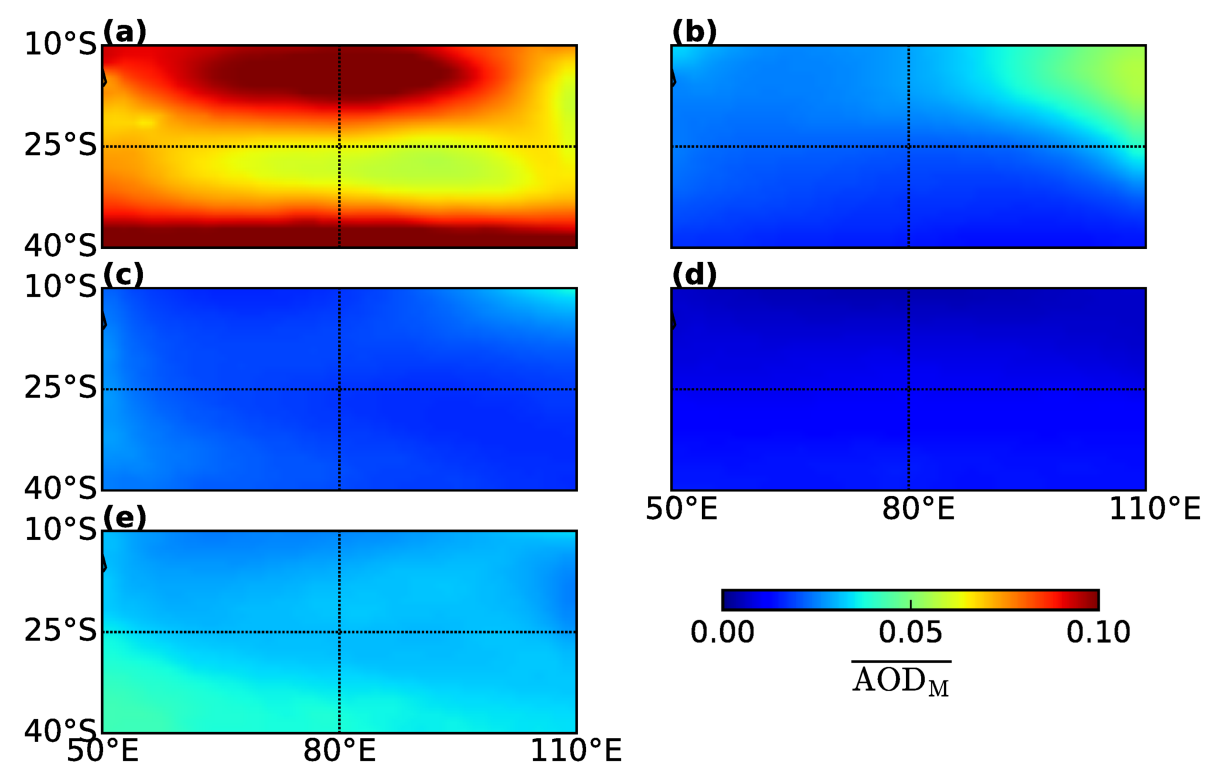

FIG. 7 - Annual averaged over the period 2007-2012 (inclusive) of the horizontal AOD field of the five aerosol species as given by MACC: (a) SSA, (b) dust, (c) organic matter, (d) black carbon, and (e) sulfate. 


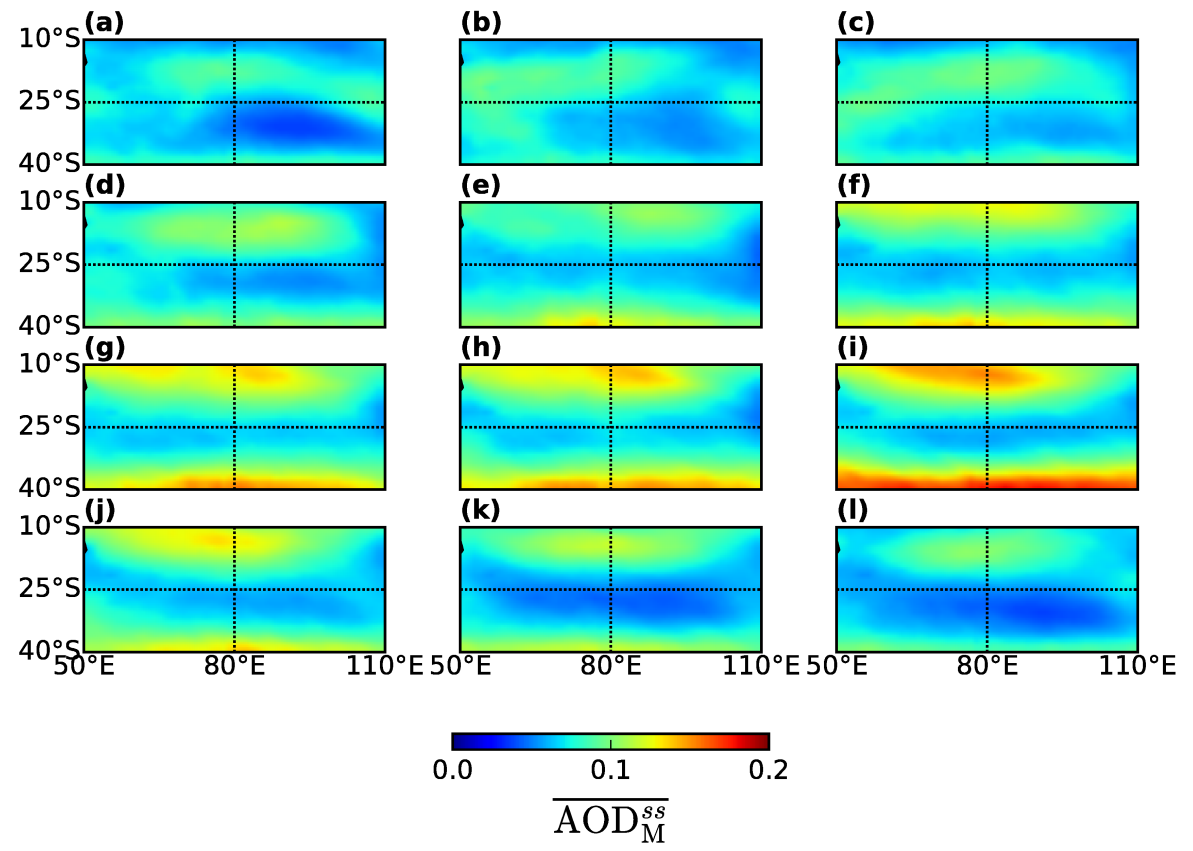

FIG. 8 - Horizontal field of the monthly averaged (from 2005 to 2012 inclusive) MACC SSA $A O D, \overline{A O D_{M}^{s s}}$ from January (a) to December (l).

\subsubsection{Sea salt distributions}

The monthly averaged MACC sea salt $A O D\left(A O D_{M}^{s s}\right)$ is displayed in Figure 8. The values range from around 0.05 to 0.16 . SSA emissions depend on the near surface wind speed because SSA particles are mainly formed at the sea surface by various mechanical processes (Woodcock, 1948; Boyce, 1951, 1954, 15 Blanchard, 1963; Monahan et al., 1986, Lewis and Schwartz, 2004) like breaking waves via bubble bursting and direct tearing of wave crests under high wind speed conditions. Thus, it is worth analyzing the near-surface wind $\left(W_{h}=\right.$ $\left(U^{2}+V^{2}\right)^{1 / 2}, U$ and $V$ being the zonal and meridional components, respectively) circulation in the area (Fig. 9). As already suggested by Figure 5 , it is organized as a gyro centered on the Mascarenes anticyclone. The values of $W_{h}$ are low in the anticyclone $\left(W_{h} \approx 6 \mathrm{~m} \mathrm{~s}^{-1}\right)$ and in the $\operatorname{ITCZ}\left(W_{h} \approx 3 \mathrm{~ms}^{-1}\right)$. Two higher speed zones $\left(W_{h}>7 \mathrm{~m} \mathrm{~s}^{-1}\right)$ can be identified to the north and to the south of 
the anticyclone. The first one is westward and corresponds to the tradewinds, while the second is eastward and is the circumpolar circulation. This relatively high wind speed can explain the contamination of the oceanic area by land aerosol emissions (from Australia to the north and from Africa to the south). This circulation appears to be very stable, the main seasonal variation being a meridional modulation, as previously described for the ITCZ. During January, February, and December (Fig. 9a, b, l), the high wind speed area to the north of the anticyclone is roughly contained between $12^{\circ} \mathrm{S}$ and $25^{\circ} \mathrm{S}$. From May (Fig. 9e) to September (Fig. 9i), this organization moves northward, and presents two high wind speed areas $\left(10^{\circ} \mathrm{S}-20^{\circ} \mathrm{S}\right.$ and $\left.35^{\circ} \mathrm{S}-40^{\circ} \mathrm{S}\right)$ with no specific zonal variations. Transitions between those two extreme states occur during March and April (Fig. 9k, d) on one side, and October and November (Fig. 9., k) on the other side.

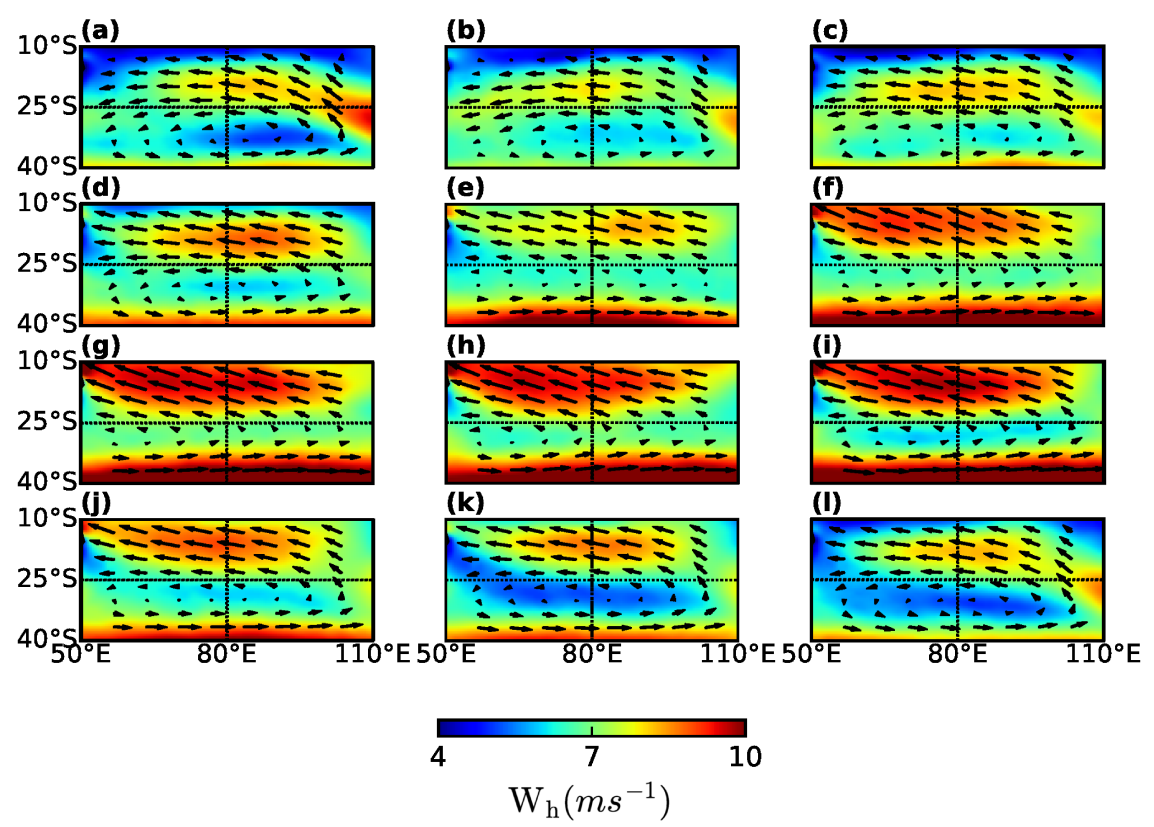

FIG. 9 - Horizontal field of the monthly averaged (from 2005 to 2012 inclusive) wind field $W_{h}$ by ERA-I from January (a) to December (l).

The $W_{h}$ field is closely related to the $A O D_{M}^{s s}$ field. As expected, the highest 
values of $A O D_{M}^{s s}\left(\overline{A O D_{M}^{s s}}>0.1\right)$ correspond to the highest wind speeds $\left(W_{h}>\right.$ $8 \mathrm{~m} \mathrm{~s}^{-1}$ ). To further examine this relationship, we now compare the $A O D_{M}^{s s}$ field to the field of the monthly averaged sea salt emission flux $\Phi_{s s}$, over the period 2005-2012 (Fig. 10), as parametrized by the relationship suggested by (Ovadnevaite et al., 2014, Fig. 1). This parametrization does not consider $\Phi_{s s}$ as depending only on the wind stress at the sea surface. Rather, $\Phi_{s s}$ is dependent on the Reynolds number Re of the sea surface. This number is calculated by means of the ECMWF wave model (WAM). This model assimilates wave characteristics from satellite altimetry data (Abdalla et al. 2010) to provide data on a $0.75^{\circ} \times$ $0.75^{\circ}$ lat/lon grid available with a time step of $6 \mathrm{~h}$. This parametrization depends not only on the instantaneous or mean wind stress on the ocean surface, but also on the sea surface state since it includes wave height, wind history, friction velocity, and viscosity (see Ovadnevaite et al. (2014) for details). Precisely:

$$
R e=C_{d}^{1 / 2} \frac{U_{10} H_{s}}{V_{w}}
$$

where $C_{d}$ is the mean drag coefficient, $H_{s}$ the significant height of wind waves, $U_{10}$ the $10 \mathrm{~m}$ wind speed, and $V_{w}$ the kinematic viscosity. The latter has been deduced from Eq. 22 and 23 of Sharqawy et al. (2010). For that, $\operatorname{SST}^{9}$ values are taken from ERA-Interim, and a water salinity of $0.035 \mathrm{~kg} \mathrm{~kg}^{-1}$ and a water density of $1025 \mathrm{~kg} \mathrm{~m}^{-3}$ are assumed throughout the area considered. Within the highest wind speed areas $\left(W_{h}>8 \mathrm{~m} \mathrm{~s}^{-1}\right), \Phi_{s s} \approx 20 \mathrm{ng} \mathrm{m}^{2} \mathrm{~s}^{-1}$, while $\Phi_{s s}<$ $10 \mathrm{ng} \mathrm{m}^{2} \mathrm{~s}^{-1}$ within the anticyclonic area and the ITCZ. Overall, the $\Phi_{s s}$ and $A O D_{M}^{s s}$ fields present on average similar patterns and evolutions during the year. This suggests that MACC provides a reliable representation of sea salt $A O D$, ${ }_{345}$ if the $A O D$ is assumed to be representative of the SSA concentration.

9. Sea Surface Temperature 


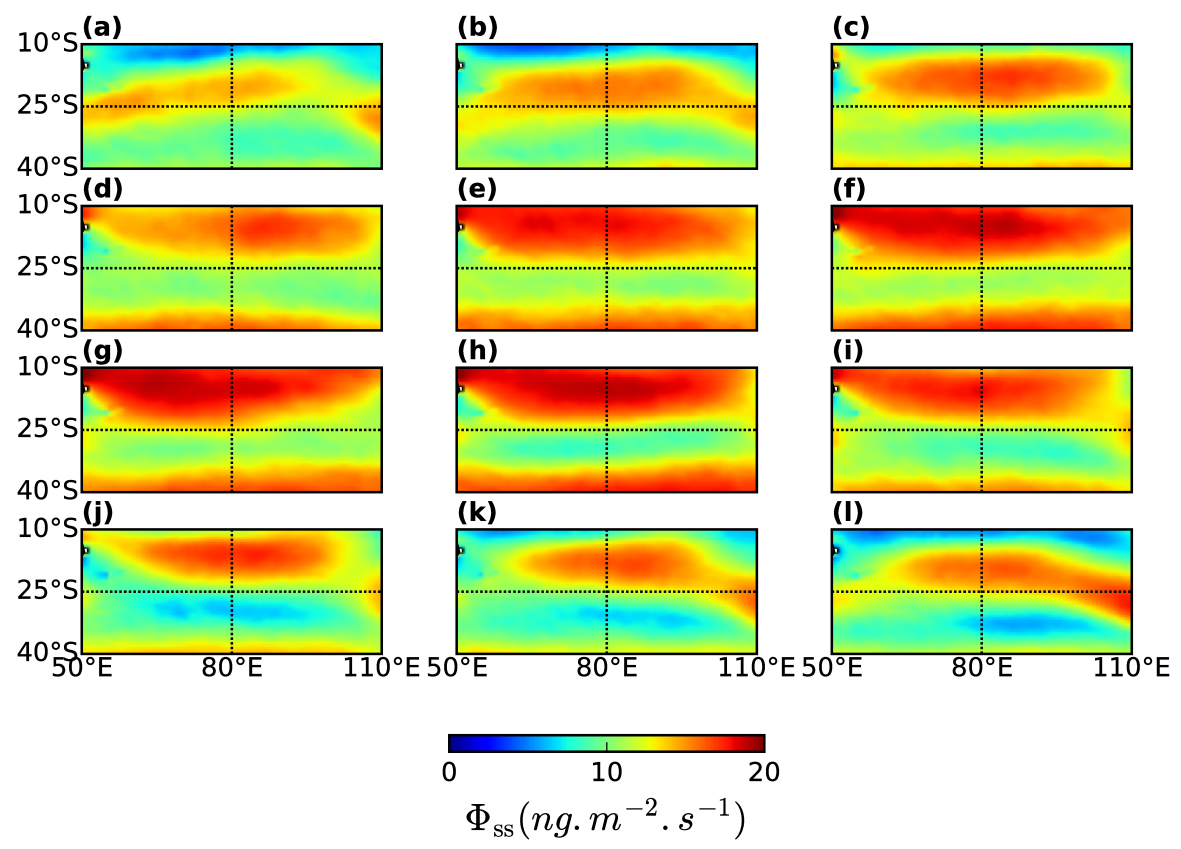

FIG. 10 - Monthly averaged SSA emission flux $\Phi_{s s}$ from 2005 to 2012 (inclusive) as given by the Ovadnevaite et al. (2014) parametrization.

\subsection{Vertical aerosol distributions}

Vertical cross sections (height-latitude) of CALIOP extinction and MACC SSA mixing ratio (for the size range $5-20 \mu \mathrm{m}$ ) are presented in Figure 11 and $\mathrm{b}$, respectively. These cross sections are meridional averages between $50^{\circ} \mathrm{E}$ and

$110^{\circ} \mathrm{E}$ and a temporal average from 2005 to 2012 (inclusive). Since mixing ratio is proportional to the mass of SSA in a given volume of air, it is assumed to be a proxy of SSA concentration, as is the $A O D$. The vertical bars at $40^{\circ} \mathrm{S}$ and $10^{\circ} \mathrm{S}$ (i. e. -40 and -10 ) indicate our area of investigation. In the Figure, we have extended the domain in order to have a better representation. Both vertical cross sections reveal very low quantities above $800 \mathrm{hPa}(2 \mathrm{~km}$ asl), indicating that the aerosols analyzed above, according to horizontal cross sections, are mainly limited to low atmospheric layers.

The highest values of CALIOP extinction observed below $2 \mathrm{~km}$ are likely associated with the highest values of the SSA mixing ratio as given by MACC: in 
January, maximum values are located between $60^{\circ} \mathrm{S}-50^{\circ} \mathrm{S}$ and around $20^{\circ} \mathrm{S}$. These two locations are slightly translated northward in July compared to January. The CALIOP extinction presents also a high value close to the Equateur which is not given by MACC. This analysis, performed by considering 8 years of data, agrees with the vertical cross section displayed in (IPCC, 2013, p. 599, 365 Fig. 7.14e) for the year 2010. This may be explained by the wind circulation displayed in Figure 11k; namely, the averaged zonal wind (arrows) and the averaged vertical velocity (in $\mathrm{Pas}^{-1}$ : negative values correspond to ascending motion while positive values are associated with descending motion). Figure $11 \mathrm{~d}$ is the averaged near-surface wind speed. The highest values of the zonal wind, located close to the ascending branch of the Hadley cell, are associated with the two maximum locations described above. On the contrary, the regions where the SSA mixing ratio are low (around $40^{\circ} \mathrm{S}-30^{\circ} \mathrm{S}$ in January and $30^{\circ} \mathrm{S}-20^{\circ} \mathrm{S}$ in July) correspond to the descending branch of the Hadley cell. 

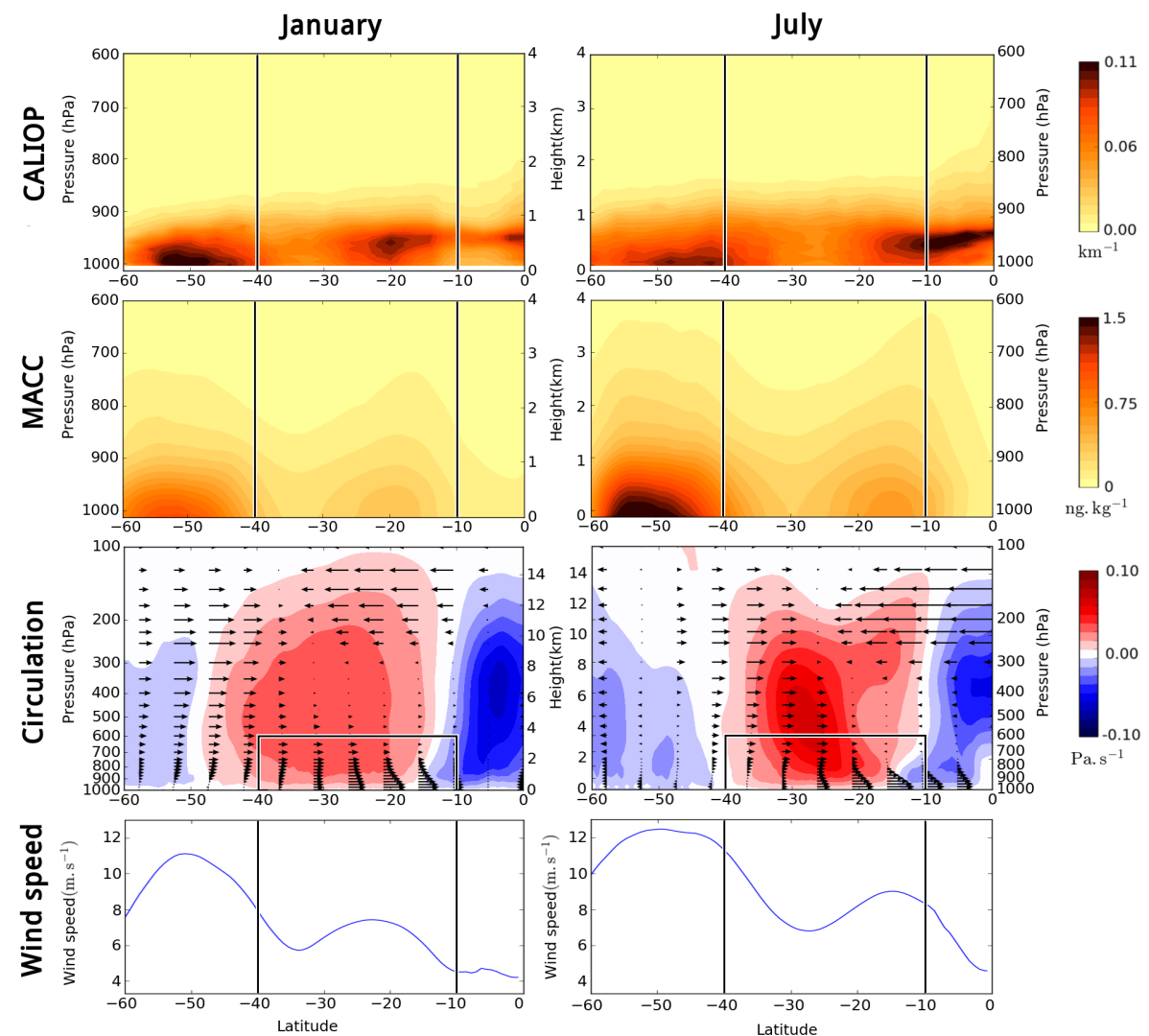

FIG. 11 - Meridional averages (between $50^{\circ} \mathrm{E}$ and $110^{\circ} \mathrm{E}$ of longitude) and temporal average (from 2005 to 2012 inclusive) of the CALIOP extinction (first row), MACC mixing ratio (second row), wind circulation (third row) and wind speed (fourth row). The black vertical lines at $-40^{\circ}$ and $-10^{\circ}$ indicate the south latitudes of our area of study. The black rectangle on the subfigures of the third row indicates the zone considered on the other rows.

The vertical distributions have also been studied for the other sea salt aerosol sizes and the four other aerosol species considered in the MACC reanalysis. In order not to present excessive Figures, we do not show these vertical distributions, but we can say that: (1) the smaller SSA (range size from 0.03 to $0.5 \mu \mathrm{m}$ ) are mixed above the marine boundary layer until almost the tropopause; (2) the

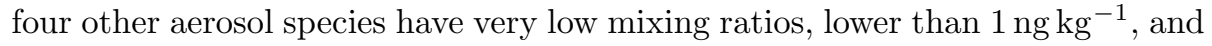
the presence of Australian and African contamination also appears in the verti- 
cal distributions. Dust and organic matter are located higher in the atmosphere than sea salts, between $800 \mathrm{hPa}$ and $600 \mathrm{hPa}$ (i.e. $2 \mathrm{~km}$ and $4 \mathrm{~km}$ ). (3) There are no significant traces of terrestrial aerosols in the center of the area because of the Mascarenes anticyclone. Indeed, the surface divergent flow associated with this anticyclone prohibits eventual horizontal transport of air masses with high aerosol concentrations. In addition, the subsident air masses coming from near the tropopause are likely poor in aerosol and/or carrying small particles that do not contribute significantly to $A O D$.

\subsection{Impact of the MJO on the aerosol distributions}

We have shown above that the wind circulation over the area under study, and consequently the sea salt burden, presents some general characteristics that are rather stable. However, some disturbances in the circulation may occur, such as the Madden-Julian Oscillation (MJO) (Madden and Julian, 1972), which can influence the distribution of aerosols. The MJO is a perturbation of largescale deep convection existing inside the ascending branch of the Hadley cell. It consists in the setting up of a zonal circulation between an area of suppressed convection and an area of reinforced convection. This perturbation moves slowly from west to east, at around $5 \mathrm{~m} \mathrm{~s}^{-1}$, with a period between 30-90 days, reaching its maximum amplitude over the Indian Ocean and Indonesia. The MJO lifecycle can be divided into 8 phases, according to the motion state, each phase being associated with an index. This oscillation affects many climatic features, such as the Asian and Australian monsoon (e. g. Wheeler and McBride, 2005), the North Atlantic circulation (Cassou et al., 2005) or extreme events (e. g. Jones et al., 2004). However, its impact on atmospheric composition is still a relatively new area of investigation. Tian et al. (2008) have studied the modulation of aerosols by the MJO using several satellite aerosol products. In particular, they found a positive correlation between MODIS/AVHRR ${ }^{10}$ AOD

10. Moderate Resolution Imaging Spectroradiometer / Advanced Very High Resolution Radiometer 
measurements and TRMM ${ }^{11}$ rainfall anomalies associated with the MJO, and concluded that the impact of the MJO on aerosol burden could be mainly due to cloud contamination in the aerosol retrievals. More recently, (DeWitt et al. 2013. Fig. 12) have shown, from field campaign measurements, that the MJOassociated convection modifies wind dynamics and, as a consequence, changes the concentration of SSA distributions over the equatorial Indian Ocean; especially, increased wind speeds during MJO convectively-active periods greatly enhances SSA concentrations. In the following, we present some results that lend support to the hypothesis of DeWitt et al. (2013).

The progression of the MJO is displayed in Figure $12 \mathrm{a}$ as the TRMM precipitation rate, corresponding to each phase of the MJO, because the reinforced convection, characteristic of the MJO, comes with rainfall enhancement.

most important values of $\triangle A O D_{P}$ are mainly limited close to the equatorial band, where the MJO is located. The anomaly values is \pm 0.05 . The extreme positive value $(+0.05)$ corresponds to enhanced convection (phases 2-3) while negative values $(-0.05)$ correspond to suppressed convection (phases 6-7). These ${ }_{435}$ have been circled by black ellipses in Fig. 12 b. Low and intermediate values of $\triangle A O D_{P}$ are associated with the transitional phases 1-8 and 4-5. A similar field

11. Tropical Rainfall Measuring Mission 
is observed for $\triangle A O D_{M}$ (Fig. 12, ). This suggests that MACC correctly represents the $A O D$ variability due to the MJO. From these results, it follows that a significant impact of the MJO appears to be restricted to the northern edge ${ }_{440}$ (from $10^{\circ} \mathrm{S}$ to $20^{\circ} \mathrm{S}$ ) of our area of investigation. Anomalies can also be computed for each of the five classes of aerosols available in MACC. However, we put focus on SSA which is the dominant class. Precisely, we have computed anomalies of SSA emission flux $\left(\Delta \Phi_{s s}\right)$ for each phase of the MJO (Fig. 12 $\mathrm{d}$ ). The behavior of $\triangle \Phi_{s s}$ is the same as that of $\triangle A O D_{P}$ and $\triangle A O D_{M}$ : in the northern part of the area, $\Delta \Phi_{s s}$ is maximal $\left(+4 \mathrm{ng} \mathrm{m}^{-2} \mathrm{~s}^{-1}\right)$ during phases 2-3 and minimal ( $-4 \mathrm{ng} \mathrm{m}^{-2} \mathrm{~s}^{-1}$ ) during phases 6-7. Low and intermediate values correspond to the transitional MJO phases $(1-8,4-5)$. The fact that $\Phi_{s s}$ seems to be related to the MJO-associated convection corroborates the conclusion of DeWitt et al. (2013) because the SSA emission flux depends on the near-surface wind speed $\left(U_{10}\right)$. However, we can extend this hypothesis and assume that the MJO affects more generally the parameters that enter the definition of the Reynold number: in addition to wind speed, the MJO may impact the state of the sea surface $\left(C_{d}\right.$ and $\left.H_{s}\right)$ and the seawater kinematic viscosity $V_{w}$ (rain changes salinity, density and SST). The anomalies presented in this section do not appear to correspond to observational bias (cloud contamination in the retrieval for instance), although this possibility cannot be totally ruled out, but rather to a physically realistic influence of the MJO. Modeling work is needed to explore more deeply how the MJO modifies the sea surface state (wave height, viscosity, friction) and thus SSA emissions and $A O D$. We note that other disturbances, 460 like the El Niño Southern Oscillation (Kessler and McPhaden, 1995), may impact the circulation and the aerosol burden at the large scale (e.g. by favoring transport, by changing precipitation regimes and thus aerosol scavenging). We have not addressed this issue in this paper. 


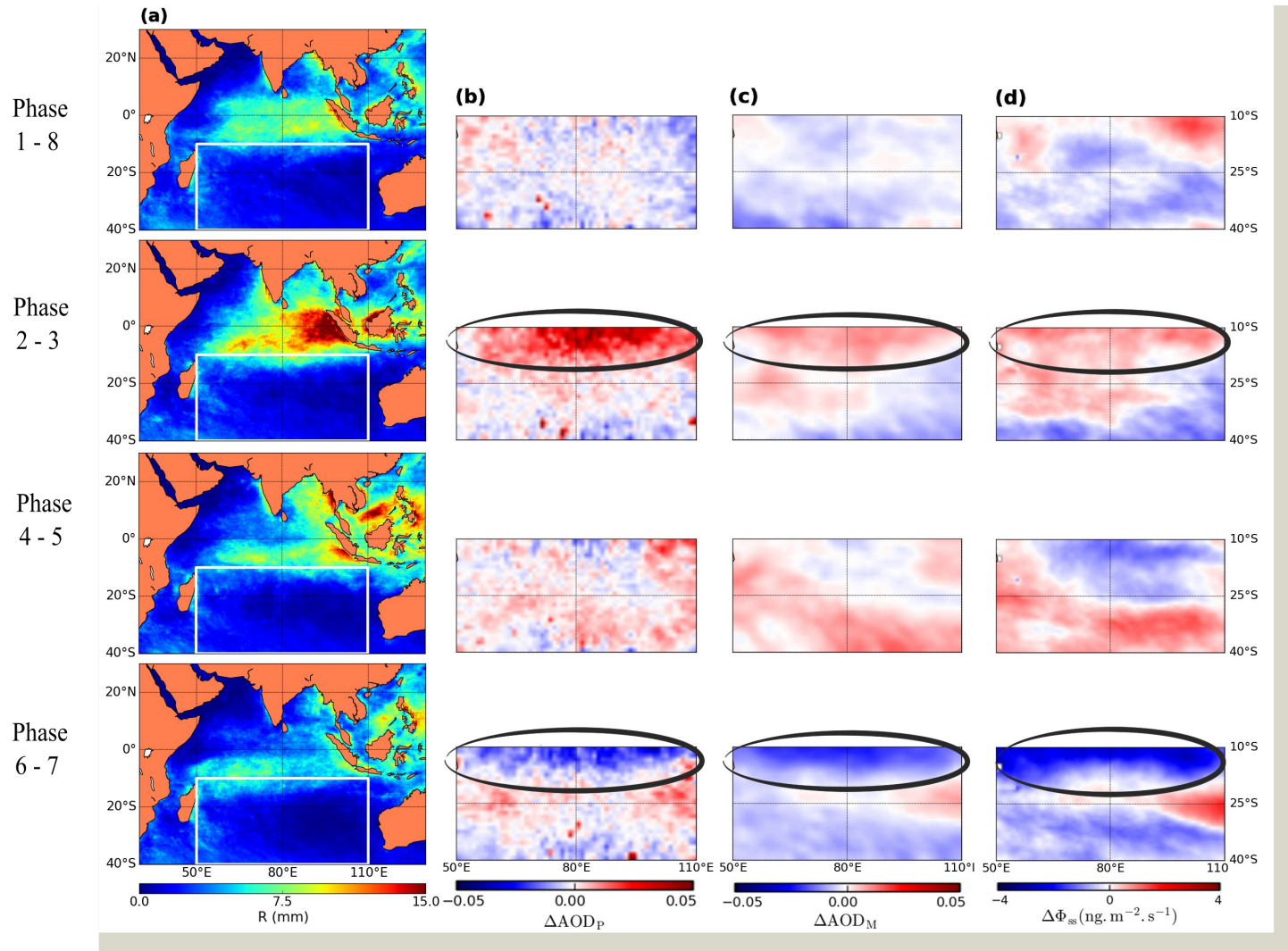

FIG. 12 - (a) Precipitation rate $R$ as measured by TRMM for each phase of the MJO and corresponding anomalies of the AOD by POLDER $\triangle A O D_{P}$ (b) and MACC $\triangle A O D_{M}(c)$, and of the SSA emission flux $\Delta \Phi_{s s}(d)$.

\section{Probability density functions}

In this section, a quantitative analysis of the aerosol distribution is performed by computing the probability density function (pdf) of the $A O D \mathrm{~s}$. The area considered is restricted to $20^{\circ} \mathrm{S}-30^{\circ} \mathrm{S}$ and $70^{\circ} \mathrm{E}-90^{\circ} \mathrm{E}$ since, according to our analysis above, this area has the highest ratio SSA/total aerosols, especially from March to November. Weak occurrences of dust occur in December, January, and February. Assuming that the optical properties do not change with time within the area, the pdfs provided are representative of the aerosol atmospheric burden. Briefly, the pdf $f(x)$ is such that the probability $p(x)$ for the variable $x$ to be 
lower than the value $x_{0}$ is (e.g. Forbes et al., 2011):

$$
p\left(0<x<x_{0}\right)=\int_{0}^{x_{0}} f(x) d x .
$$

Pdf are of interest to know how certain atmospheric variables, such as $A O D$ or species concentration, are distributed statistically. After testing fits of various analytical functions, the lognormal distribution turned out to be the most suitable to describe $A O D$, as recognized previously by (O'Neil et al. 2000). This is not surprising since this distribution is frequently used to describe atmospheric variables of various types. For instance, it is used to describe statistically humidity (Louf et al., 2015, Soden and Bretherton, 1993: Yang and Pierrehumbert, 1994) and rain properties (Mesnard and Sauvageot, 2003, Atlas et al., 1990. Sauvageot, 1994, Sauvageot and Lacaux, 1995, Foster et al., 2006). Physically, the lognormal distribution is associated with the statistical process of propor475 tionate effects (e.g. Aitchison and Brown, 1966, Crow and Shimizu, 1987): the change in the variate at any step of the process is a random proportion of the previous value of the variate.

The general expression of the lognormal function is, with $y=\ln x$ :

$$
f(x ; \mu, \sigma)=\frac{1}{x \sigma(2 \pi)^{1 / 2}} \exp \left[-\frac{1}{2}\left(\frac{y-\mu}{\sigma}\right)^{2}\right]
$$

where $\mu$ and $\sigma^{2}$ are respectively the expected value and the variance of $y$. These quantities are defined through the expected value and the standard deviation of $x\left(\mu_{x}\right.$ and $\sigma_{x}$ respectively):

$$
\mu=\ln \left\{\mu_{x}\left[1+\left(\frac{\sigma_{x}}{\mu_{x}}\right)^{2}\right]^{1 / 2}\right\}
$$

and

$$
\sigma^{2}=\ln \left[1+\left(\frac{\sigma_{x}}{\mu_{x}}\right)^{2}\right]
$$

Figure $13 \mathrm{a}, \mathrm{b}, \mathrm{c}$, and d display, respectively, the $A O D$ pdfs of AERONET, POLDER, MACC (for SSA and sulfate aerosols), MACC total (for the five aerosol species), with their corresponding lognormal fits. Each of these pdfs is precisely an annual averaged-pdf over the whole period 2005-2012 (inclusive). 
We do not show the pdf for each month in order to not present excessive Figures and because the pdfs do not show any significant seasonal variation: their form is nearly constant throughout the year (on average over 2005-2012), they are unimodal and quite well fitted by lognormal distributions. Figure $13 \mathrm{a}, \mathrm{b}, \mathrm{c}$, and d shows that the four annual averaged-pdfs are similar whatever the $A O D$ data considered (i. e. AERONET, POLDER, MACC) : they are unimodal with the most frequent $A O D$ values lower than 0.1 (Fig. $13 \mathrm{k}, \mathrm{b}, \mathrm{c}$ ); these pdfs peak for $A O D \lesssim 0.1$ and extend very slowly up to $A O D=0.5$. On Fig. 13; , focus 490 is put on SSA and sulfate aerosols. If we consider the contribution of all the five aerosol species, the pdf (Fig. 13d) is roughly shifted towards higher $A O D$ values and peak between 0.1 and 0.2 . This is likely due to the Australian and African influences already mentioned. These influences seem to be observed on the AERONET pdfs in September and October through some secondary peaks 495 at 0.3 and 0.4 (Fig. 13). 


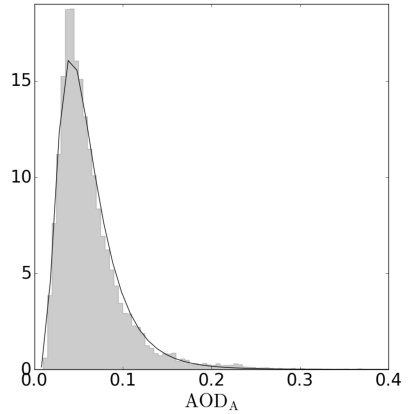

a)

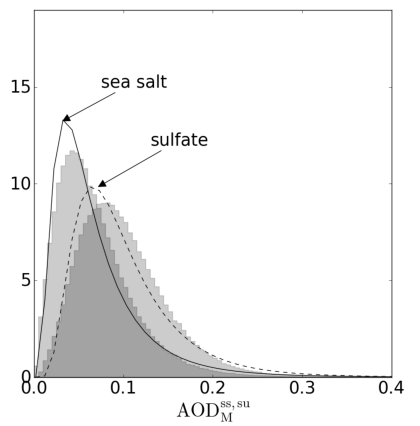

c)

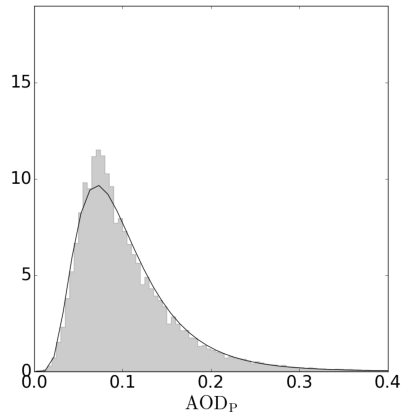

b)

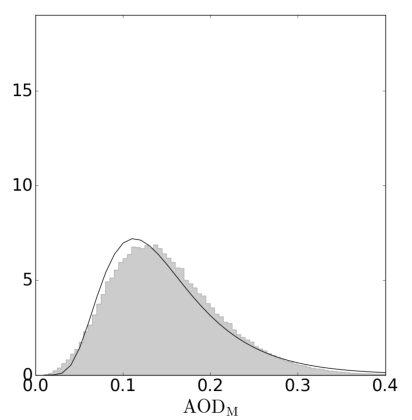

d)

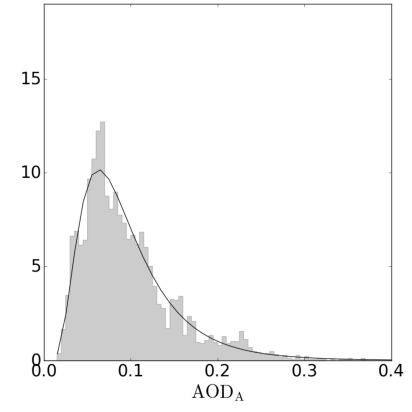

e)

FIG. 13 - Annual averaged probability density distributions (pdf) and their corresponding fits of the AOD as given by AERONET (a), POLDER (b) and MACC (c and d). On (c) focus is put on SSA and sulfate aerosols. The pdf of the AERONET AOD in September and October are displayed in (e).

These pdfs can be objectively described with the first four central moments: the mean (or average) value, the standard deviation, the skewness, and the 
kurtosis, respectively (e. g. Forbes et al., 2011). The meaning of the two first moments is well known. The skewness and the kurtosis are related respectively to the tails and to the asymmetry of the distribution. A distribution whose tails approach zero faster than a Gaussian (i. e. with few extreme outliers) has a kurtosis less than 3 and it is said to be platykurtic. On the contrary, a distribution of kurtosis higher than 3 has tails that approach zero more slowly than a Gaussian and it is said leptokurtic. Skewness can be positive or negative. Qualitatively, for a unimodal distribution, if skewness is positive (negative), the tail on the left (right) side is longer than the right (left) side. The values of these four moments, for each month, are displayed in Figure 14. Overall, and except for AERONET, the mean value $\overline{A O D}$ and the standard deviation $\sigma$ have a local minimum around June surrounded by two maxima, one at the beginning of the year (around February/March) and another at the end of the year (September/October). The $\overline{A O D}$ local minima range from 0.08 to 0.12 , and the $\overline{A O D}$ maxima that surround each local minimum range approximately from 0.11 to 0.19. For AERONET, the mean $A O D$ is almost constant, with values ranging from 0.06 to 0.08 , although a slight decreasing can be guessed. We observe the same orders of magnitude and tendencies for $\sigma$ but with smaller values. This means that the pdfs are quite stable throughout a year since $\overline{A O D}$ and $\sigma$ do not evolve significantly. Furthermore, all of the pdfs have a quasi-constant skewness $\left(\mu_{3}\right)$ greater than 1 , which implies right-tailed asymmetric pdfs with decreasing probability of occurrence of high AOD. Regarding kurtosis $\left(\mu_{4}\right)$, the pdfs are clearly leptokurtic except from August to October if we consider the total aerosol burden as given by MACC. Throughout the year, kurtosis decreases from a maximum value, which can rise up to 30, reaches a minimum in August/September and finally increases up to a second lower maximum in December. We do not have a clear explanation for these differences in the $A O D$ seasonal variability in ${ }_{525}$ AERONET and POLDER, except that AODs from AERONET are local values while $A O D$ s from POLDER are retrievals that depend on the sea surface state and on radiative transfer schemes throughout the atmosphere. Ground-based $A O D$ measurements over this region are therefore necessary. 


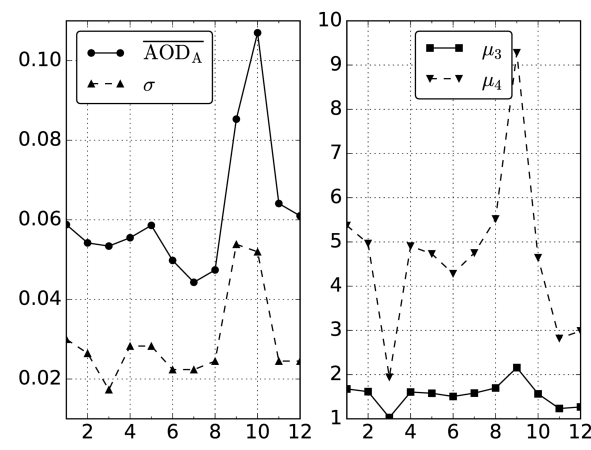

a)
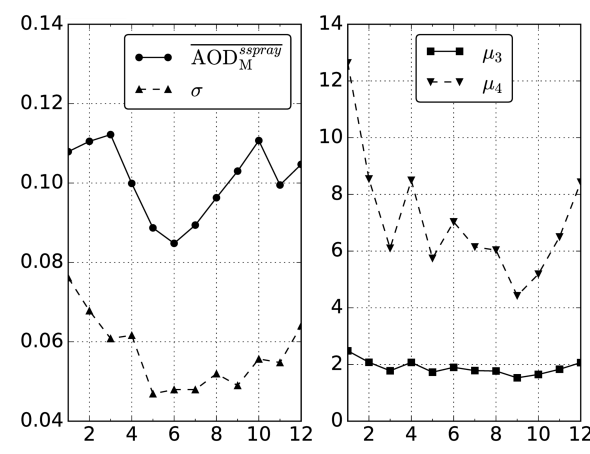

c)
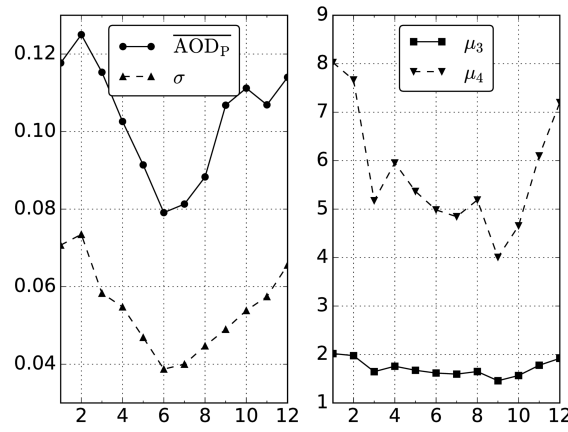

b)
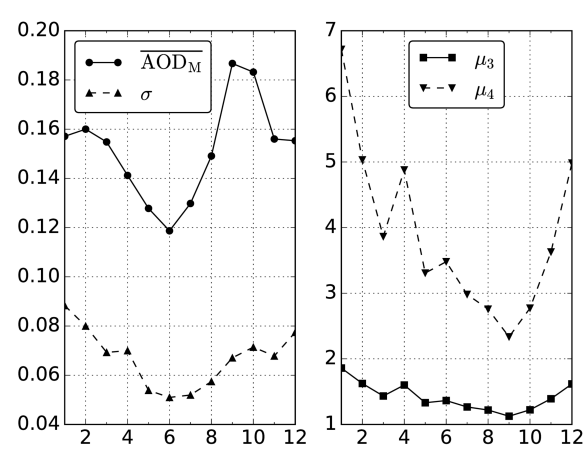

d)

FIG. 14 - Values, for each month, of the four moments of the pdfs of Fig. 13a, b, c, d.

\section{Aerosol direct radiative effect assessment}

is the so-called direct radiative effect of aerosols $\left(D R E A\right.$, in $\left.\mathrm{W} \mathrm{m}^{-2}\right)$. Herein, we have attempted to assess the fields of DREA at the TOA 12 by means of the different MACC $A O D$ fields. It is not the topic of this paper to present and use radiative transfer models. Rather, this estimation has been done using

a graphical relationship between the $A O D$ per aerosol type at $550 \mathrm{~nm}$ and the corresponding simulated $D R E A$ s proposed by (Lee et al., 2014, Fig. 1a in this

12. Top Of the Atmosphere 
reference), which is based on a radiative transfer model and MODIS observations. Our estimate field of the annually averaged DREA at TOA is presented in Figure 15. For the whole area, the mean value is $-10.9 \pm 0.3 \mathrm{~W} \mathrm{~m}^{-2}$ (uncertainty has also been computed with the help of (Lee et al., 2014, Fig. 1)). In absolute value, the $D R E A$ is lower in the centre of the area considered, i. e. where aerosol concentration is the lowest and SSA are the dominant aerosols. At the centre and the south-east of our area of study, $D R E A \approx-9 \mathrm{~W} \mathrm{~m}^{-2}$. In the presence of terrestrial aerosols, i. e. on the borders of the area, $D R E A \approx-12 \mathrm{~W} \mathrm{~m}^{-2}$. These values are higher than those of the measurement-based assessments of Yu et al. (2006) which concluded that the best estimates of mean DREA over the global cloud-free ocean is $-5.5 \pm-0.2 \mathrm{~W} \mathrm{~m}^{-2}$ at TOA. Over the Southern Indian Ocean (the considered area [numbered 11] is different from ours since it is translated westwards in such a way that it contains Africa and excludes the oceanic part close to Australia), the annually averaged DREAs at TOA, estimated from various observation instruments (as MODIS or MISRG 13 ) and aerosol models (as GOCART ${ }^{14}$ ), are between -5.1 to $-2.6 \mathrm{~W} \mathrm{~m}^{-2}$ (Yu et al. 2006). We can identify three sources of errors when computing DREA: (1) the overestimation of the MACC AOD values compared with AERONET observations. The difference with Yu et al. (2006) is reduced if we multiply the values of $D R E A$ by the ratio between MACC and AERONET AODs, assuming that this ratio does not change with time over the area of study. Indeed, in this way the mean $D R E A$ values we obtained is $-5.0 \mathrm{~W} \mathrm{~m}^{-2}$; (2) the algorithm of $D R E A$ retrieval which neglects the asymmetry of the particles; (3) the coupling between the $D R E A$ of different species. The latter means that, contrary to what usually assumed, the total $D R E A$ is not the sum of $D R E A$ per types of aerosols.

13. Multi-angle Imaging SpectroRadiometer

14. Goddard Chemistry Aerosol Radiation and Transport 


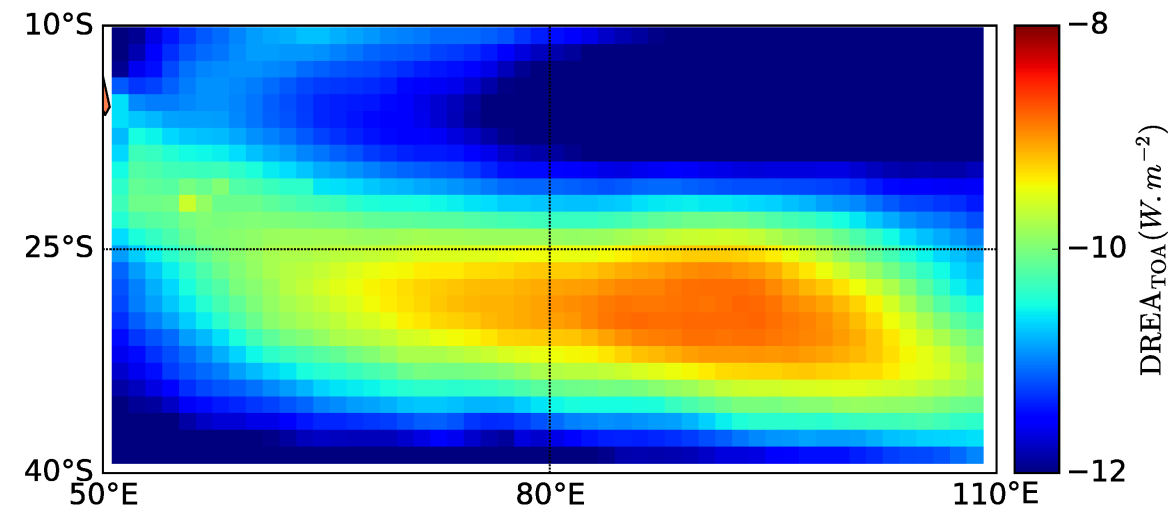

FIG. 15 - Estimated annually averaged (from 2005 to 2012 inclusive) of the DREA at TOA from MACC AOD outputs.

\section{Conclusion}

In this paper, we have analyzed, over a 8-years period (2005-2012), the aerosol variability and distribution over the Southern Indian Ocean, precisely in the area between $10^{\circ} \mathrm{S}$ and $40^{\circ} \mathrm{S}$ of latitude and $50^{\circ} \mathrm{E}$ and $110^{\circ} \mathrm{E}$ of longitude. This area has been identified as a pristine region and it is thus of interest for examining natural emissions of marine aerosols that can be reasonably considered to be close to the preindustrial conditions. Various data have been used, namely: satellite data from POLDER, MACC reanalysis (obtained from a forward aerosol model, assimilation of MODIS observations, and ECMWF weather prediction), and AERONET measurements at Saint-Denis (French Reunion Island). The period of time we have chosen (2005 - 2012 inclusive) corresponds to the period in which all of these data were available together. All of these datasets are complementary and independent from each other. Satellite observations present the advantage to obtain a large coverage of the region. However, $A O D$ retrievals are not possible in the presence of clouds in the satellite field of view and depend on an atmospheric radiative transfer model. In the case of POLDER observations over the ocean, $A O D$ measurements may be biased by the foam of ripples that reflect strongly shortwave radiations and tend to increase the signal 

these disadvantages since, by means of MODIS data assimilation and ECMWF weather predictions, it is possible to obtain a continuous (in space and time) description of the aerosols in the area studied. Local measurements from AERONET, which are recognized to be of good quality, have also been used and study were too few to be used fruitfully. This suggests the need for more measurements in this region in order to have a description at the local scale of the aerosol emission. In our study, the aerosol burden has been represented mainly by the $A O D$. By doing this, it is implicitly assumed that the optical properties of the aerosol concentration. Such an assumption is not unrealistic since the aerosol burden is mainly composed of marine aerosols. Other quantities that can be realistically considered as good proxies of aerosol concentration have also been used, namely the mixing ratio and the specific (not column-integrated) extinction coefficient. We have assumed that all of these distinct quantities can be compared.

However, despite the different nature of the data used, we have obtained a consistent description of the aerosol distribution and variability in the area under consideration. The $A O D$ is relatively low $(A O D \lesssim 0.1)$ and the aerosols are mainly sea salt and sulfate aerosols, in particular in the center of the area which is a vast region quasi pure in terms of aerosol content. In the northeast and the southwest parts of the area, there are some aerosol intrusions from Australia and South Africa.

The aerosols are mainly located in the marine boundary layer, below $2 \mathrm{~km}$ and present a spatial distribution which is relatively stable with time. This distribution is however impacted by the wind circulation at large scales: (1) the ITCZ modifies the aerosol burden in the northest part of the area of study when moving along a south-north direction and acts as a barrier that prevents Indian and Asian anthropogenic contamination; (2) the Mascarene anticyclone follows 610 a west-east direction and its location is associated with the most pristine (the 
cleanest) zone. This zone is very stable with time in terms of $A O D$. Some events like the MJO could also affect the aerosol burden in the Southern Indian Ocean. Indeed, we have noted that the most active phases of the MJO are qualitatively associated with the strongest anomalies of sea salt emissions. We hypothesize that the MJO modifies not only the wind circulation, as already suggested by previous authors, but also that it could modify all quantities (surface temperature, viscosity, drag coefficient) that are involved in the sea surface Reynold number used in the emission flux parametrization.

From a quantitative point of view, both the $A O D$ time series over the period considered and the statistical results ( $A O D$ correlation and $A O D$ pdf) share similar features. It appears clearly that the $A O D$ s given by POLDER and MACC are slightly overestimated with respect to that measured locally by AERONET. The bias is of the order of 0.05 . In addition, the MACC AODs are a little bit higher than the POLDER $A O D \mathrm{~s}$. The pdfs of the $A O D$ seem to be lognormal functions and leptokurtic. They do not show any significant seasonal variations. Their analytical properties, i. e. the four moments of the lognormal fits, have been given in order to better characterize these pdfs. They could be useful for 0D and 1D models in cloud physics devoted to understand how water vapor and aerosols interact to determine a cloud field. This feature is under study and will be presented in a future work. The annual averaged DREA at TOA, for the cleanest zone of the area studied, is estimated to be $-5.01 \mathrm{~W} \mathrm{~m}^{-2}$, in agreement with other values in the literature.

In future work, it is necessary to perform in situ measurements in the marine boundary layer at the center of the area, where sea salt is largely dominant, in order to strengthen the results presented herein. Using drones, ships, and planes that could carry on several instruments (microwave radiometer for humidity and temperature profiling, infrared radiometer and photometer for AOD measurements, aerosol chemistry analysis) would be of considerable interest. Drones, especially, should be encouraged. It is worth recalling that this area of study has not been comprehensively observed yet it is an area of interest for cloud and aerosol physics as well as climate change. 


\section{Conclusion}

In this paper, we have analyzed over a 8-year period (2005-2012 inclusive) the $A O D$ distribution and variability over the Southern Indian Ocean, precisely in the area $\left\{10^{\circ} \mathrm{S}-40^{\circ} \mathrm{S} ; 50^{\circ} \mathrm{E}-110^{\circ} \mathrm{E}\right\}$. This area has been identified as a pristine region and it is thus of interest for examining natural marine emissions that can be reasonably considered to be close to the preindustrial conditions. Various complementary data have been used: satellite data from POLDER and CALIOP, MACC reanalysis, and AERONET measurements at Saint-Denis (French Réunion Island). The 8-year period chosen corresponds to the period for which all of these data were available together. The $A O D$ can be viewed as a proxy of aerosol concentration provided that the aerosol optical properties do not change significantly with time. Such an assumption is not unrealistic since the aerosol burden is mainly composed of SSA. Other quantities (mixing ratio, not column-integrated extinction coefficient) have also been used. We have assumed that all of these three distinct quantities can be compared.

Althought the POLDER and MACC AODs are slightly overestimated (by about 0.05$)$ with respect to the AERONET local measurements, we have obtained a consistent description of the aerosol distribution and variability for the Southern Indian Ocean. The main results can be summarized as follows:

- Aerosols are mainly located below $2 \mathrm{~km}$ asl and consist of SSA, especially in the center of the area where $A O D \lesssim 0.1$. There, SSA represents 60 to $80 \%$ of the total $A O D$ on average; sulfate and organic matter have very low contributions $(A O D<0.04$ and 0.02 resp.).

- Some seasonal Australian and South African aerosol intrusions $(A O D>$ 0.1 ) occur in the northeast and the southwest part of the area.

- The most pristine zone (i.e. where SSA are dominant) is quite stable with time in terms of $A O D$ and corresponds to the location of the Mascarene anticyclone. 
- The $A O D$ pdfs in the center of the area are leptokurtic, well fitted by lognormal functions, and without any significant seasonal variations.

- The $A O D$ pattern shows a striking latitudinal gradient that follows the ITCZ motion and thus suggests that the ITCZ acts as a natural barrier that prevents (if not reduces) Indian and Asian contamination for the whole year.

- The most active phases of the MJO are qualitatively associated with the strongest anomalies of SSA emissions, especially in the northern part of the area investigated. We hypothesize that the MJO can modify all the quantities (SST, viscosity, drag coefficient, wind velocity) involved in the sea surface Reynold number.

- The estimated annual averaged DREA at TOA, for the pristine zone of the area studied, is around $-9 \mathrm{~W} \mathrm{~m}^{-2}$.

Due to the long period of time considered (almost a decade), this paper stren685 ghens some observations performed during previous field campaigns and completes them by showing monthly the variability of the marine aerosols in the Southern Indian Ocean.

In order to strengthen some of these results, it is necessary to perform in situ measurements in the marine boundary layer at the center of the area. Using drones, ships, and planes that could carry on several instruments (microwave radiometer for humidity and temperature profiling, infrared radiometer and photometer for $A O D$ measurements, aerosol chemistry analysis) would be of considerable interest. Drones, especially, should be encouraged. A field campaign involving some of the auhors will be organized around Réunion Island in 2018 and 2019. It is worth recalling that this area of study has not been comprehensively observed yet it is an area of interest for cloud and aerosol physics as well as climate change investigations.

\section{Appendix: summarizing list of the most important acronyms used}

AOD: Aerosol Optical Depth 
AERONET: AErosol Robotic NETwork

AEROMAN: AEROsol MAritime Network

CALIOP: Cloud-Aerosol Lidar with Orthogonal Polarization

CALIPSO: Cloud-Aerosol Lidar and Infra-red Pathfinder Satellite Observation

705

GOCART: Goddard Chemistry Aerosol Radiation and Transport

MISR: Multi-angle Imaging SpectroRadiometer

ECMWF: European Center for Medium-range Weather Forecasts

POLDER/PARASOL: Polarisation and directionality of the Earth's Reflectances/ Polarization and Anisotropy of Reflectances for Atmospheric science

710

720

\section{Acknowledgements}

We are grateful to the Labex CAPPA which has funded this work in the 725 context of the « Cloud-aerosol interactions » work package. We acknowledge the ECMWF for providing freely reanalysis. We are also grateful to the Fulbright Committee which, by means of funding for United States-France scientific researcher exchanges, facilitates our collaboration and permits our investigations 
in Statistical Physics for Atmospheric Cloud Systems (SPACS group).

Abdalla, S., Janssen, P., Bidlot, J.R., 2010. Jason-2 OGDR wind and wave products: Monitoring, validation and assimilation. Marine Geodesy 33, 239255 .

Aitchison, J., Brown, A., 1966. The lognormal distribution. Cambridge Univer-

Ångström, A., 1929. On the atmospheric transmission of sun radiation and on dust in the air. Geografiska Annaler 11, 156-166.

Atlas, D., Rosenfeld, D., Short, D.A., 1990. The estimation of convective rainfall by area integrals: 1 . the theoretical and empirical basis. J. Geophys. Res.-

Barbosa, P.M., Stroppiana, D., Grégoire, J.M., Cardoso Pereira, J.M., 1999. An assessment of vegetation fire in Africa (1981-1991): Burned areas, burned biomass, and atmospheric emissions. Global Biogeochemical Cycles 13, 933950.

Blanchard, D.C., 1963. The electrification of the atmosphere by particles from bubbles in the sea. Progress in oceanography 1, 73IN7113-112202.

Blanchard, D.C., 1985. Flow of Electrical Current From World Ocean to Atmosphere. J. Geophys. Res. 1, 9147-9148.

Boyce, S.G., 1951. Source of atmospheric salts. Science 113, 620-621.

755 Boyce, S.G., 1954. The salt spray community. Ecological monographs 24, 29-67.

Bréon, F.M., Colzy, S., 1999. Cloud detection from the spaceborne POLDER 
instrument and validation against surface synoptic observations. Journal of Applied Meteorology 38, 777-785.

Cassou, C., Terray, L., Phillips, A.S., 2005. Tropical Atlantic influence on European heat waves. Journal of climate 18, 2805-2811.

Chen, H., Cheng, T., Gu, X., Li, Z., Wu, Y., 2015. Evaluation of Polarized Remote Sensing of Aerosol Optical Thickness Retrieval over China. Remote Sensing 7, 13711-13728. doi 10.3390/rs71013711.

Collins, W.D., Rasch, P.J., Eaton, B.E., Fillmore, D.W., Kiehl, J.T., Beck, C.T., Zender, C.S., 2002. Simulation of aerosol distributions and radiative forcing for INDOEX: Regional climate impacts. Journal of Geophysical Research: Atmospheres 107, 8028.

Crow, E.L., Shimizu, K., 1987. Lognormal Distributions: Theory and Applications. Statistics: A Series of Textbooks and Monographs, Taylor \& Francis.

Dee, D.P., Uppala, S.M., Simmons, A.J., Berrisford, P., Poli, P., Kobayashi, S., Andrae, U., Balmaseda, M.A., Balsamo, G., Bauer, P., et al., 2011. The ERAInterim reanalysis: Configuration and performance of the data assimilation system. Quarterly Journal of the royal meteorological society 137, 553-597.

DeWitt, H., Coffman, D.J., Schulz, K.J., Alan Brewer, W., Bates, T.S., Quinn, P.K., 2013. Atmospheric aerosol properties over the equatorial Indian Ocean and the impact of the Madden-Julian Oscillation. Journal of Geophysical Research: Atmospheres 118, 5736-5749. doi:10.1002/jgrd.50419.

Dubovik, O., Holben, B.N., Lapyonok, T., Sinyuk, A., Mishchenko, M.I., Yang, P., Slutsker, I., 2002. Non-spherical aerosol retrieval method employing light scattering by spheroids. Geophysical Research Letters 29 .

Dubovik, O., King, M.D., 2000. A flexible inversion algorithm for retrieval of aerosol optical properties from Sun and sky radiance measurements. Journal of Geophysical Research: Atmospheres 105, 20673-20696.

Emanuel, K., 2003. A Similarity Hypothesis for Air-Sea Exchange at Extreme 785 - Wind Speeds. Journal of the Atmospheric Sciences 60, 1420-1428. doi 10. 1175/1520-0469(2003)060<1420:ASHFAE >2.0.CD;2. 
Fitzgerald, J.W., 1991. Marine aerosols: A review. Atmospheric Environ-

q ment. Part A. General Topics 25, 533 - 545. doi/https://doi.org/10.1016/ 0960-1686(91)90050-H

Forbes, C., Evans, M., Hastings, N., Peacock, B., 2011. Statistical Distributions. Wiley.

Foster, J., Bevis, M., Raymond, W., 2006. Precipitable water and the lognormal distribution. J. Geophys. Res.-Atmos. 111. doi:10.1029/2005JD006731.

Gantt, B., Meskhidze, N., 2013. The physical and chemical characteristics of marine primary organic aerosol: a review. Atmos. Chem. Phys. 13, 3979-3996.

Hamilton, D., Lee, L., Pringle, K., Reddington, C.L., Spracklen, D., Carslaw, K., 2014. Occurrence of pristine aerosol environments on a polluted planet. PNAS 111, 18466-18471.

Hamilton, J.F., Allen, G., Watson, N.M., Lee, J.D., Saxton, J.E., Lewis, A.C., Vaughan, G., Bower, K.N., Flynn, M.J., Crosier, J., Carver, G.D., Harris, N.R.P., Parker, R.J., Remedios, J.J., Richards, N.A.D., 2008. Observations of an atmospheric chemical equator and its implications for the tropical warm pool region. Journal of Geophysical Research: Atmospheres 113, n/a-n/a. doi:10.1029/2008JD009940.

Holben, B.N., Eck, T.F., Slutsker, I., Tanre, D., Buis, J.P., Setzer, A., Vermote, E., Reagan, J.A., Kaufman, Y.J., Nakajima, T., et al., 1998. AERONET-A federated instrument network and data archive for aerosol characterization. Remote sensing of environment 66, 1-16.

Holben, B.N., Tanre, D., Smirnov, A., Eck, T.F., Slutsker, I., Abuhassan, N., Newcomb, W.W., Schafer, J.S., Chatenet, B., Lavenu, F., et al., 2001. An emerging ground-based aerosol climatology: Aerosol optical depth from AERONET. Journal of Geophysical Research: Atmospheres 106, 12067-12097.

IPCC, ., 2013. Climate Change 2013: The Physical Science Basis. Contribution of Working Group I to the Fifth Assessment Report of the Intergovernmental Panel on Climate Change.

Jaeglé, L., Quinn, P.K., Bates, T.S., Alexander, B., Lin, J.T., 2011. Global 
distribution of sea salt aerosols: new constraints from in situ and remote sensing observations. Atmospheric Chemistry and Physics 11, 3137-3157. doi:10.5194/acp-11-3137-2011.

Jones, C., Waliser, D.E., Lau, K.M., Stern, W., 2004. Global occurrences of extreme precipitation and the Madden-Julian oscillation: observations and predictability. Journal of Climate 17, 4575-4589.

Kessler, W.S., McPhaden, M.J., 1995. Oceanic equatorial waves and the 1991-93 El Niño. Journal of Climate 8, 1757-1774.

Koren, I., Dagan, G., Altaratz, O., 2014. From aerosol-limited to invigoration of warm convective clouds. Science 344, 1143-1146. doi:10.1126/science. 1252595

Lawrence, M.G., Lelieveld, J., 2010. Atmospheric pollutant outflow from southern Asia: a review. Atmospheric Chemistry and Physics 10, 11017.

Lawrence, M.G., Rasch, P.J., von Kuhlmann, R., Williams, J., Fischer, H., de Reus, M., Lelieveld, J., Crutzen, P.J., Schultz, M., Stier, P., Huntrieser, H., Heland, J., Stohl, A., Forster, C., Elbern, H., Jakobs, H., Dickerson, R.R., 2003. Global chemical weather forecasts for field campaign planning: predictions and observations of large-scale features during MINOS, CONTRACE, and INDOEX. Atmospheric Chemistry and Physics 3, 267289. doi $10.5194 / \mathrm{acp}-3-267-2003$

Lee, J., Kim, J., Lee, Y.G., 2014. Simultaneous retrieval of aerosol properties and clear-sky direct radiative effect over the global ocean from MODIS. Atmospheric environment 92, 309-317.

Lewis, E.R., Schwartz, S.E., 2004. Sea Salt Aerosol Production: Mechanisms, Methods, Measurements, and Models - A Critical Review. Geophysical Monograph Series, Wiley.

Li, F., Ramanathan, V., 2002. Winter to summer monsoon variation of aerosol optical depth over the tropical Indian Ocean. Journal of Geophysical Research: Atmospheres 107.

Liu, Z., Vaughan, M.A., Winker, D.M., Hostetler, C.A., Poole, L.R., Hlavka, 
D., Hart, W., McGill, M., 2004. Use of probability distribution functions for discriminating between cloud and aerosol in lidar backscatter data. Journal of Geophysical Research: Atmospheres 109.

Liu, Z., Voelger, P., Sugimoto, N., 2000. Simulations of the observation of clouds and aerosols with the Experimental Lidar in Space Equipment system. Applied optics 39, 3120-3137.

Louf, V., Pujol, O., Sauvageot, H., Ridi, J., 2015. Seasonal and diurnal water vapour distribution in the sahelian area from microwave radiometric profiling observations. Quarterly Journal of the Royal Meteorological Society 141, 2643-2653. doi $10.1002 / \mathrm{qj} .2550$.

Madden, R.A., Julian, P.R., 1972. Description of global-scale circulation cells in the tropics with a 40-50 day period. Journal of the atmospheric sciences 29, 1109-1123.

Menon, H.B., Hulswar, S., Anilkumar, N., Thelakkat, A.C., Moorthy, K.K., Babu, S., 2015. Spatial heterogeneity in spectral variability of aerosol optical depth and its implications to aerosol radiative forcing in the Tropical Indian Ocean and in the Indian Ocean Sector of Southern Ocean. Deep Sea Research Part II: Topical Studies in Oceanography 118, 142-151.

Mesnard, F., Sauvageot, H., 2003. Structural characteristics of rain fields. J. Geophys. Res.-Atmos. 108. doi 10.1029/2002JD002808.

Monahan, E.C., Spiel, D.E., Davidson, K.L., 1986. A model of marine aerosol generation via whitecaps and wave disruption, in: Oceanic whitecaps. Springer, pp. 167-174.

Moorthy, K.K., Saha, A., Niranjan, K., Pillai, P.S., 1999. Optical properties of atmospheric aerosols over the Arabian Sea and Indian Ocean: North-south contrast across the ITCZ. Current Science , 956-960.

Morcrette, J.J., Boucher, O., Jones, L., Salmond, D., Bechtold, P., Beljaars, A., Benedetti, A., Bonet, A., Kaiser, J.W., Razinger, M., et al., 2009. Aerosol 
casts integrated forecast system: Forward modeling. Journal of Geophysical Research: Atmospheres 114.

Myhre, G., Stordal, F., Johnsrud, M., Ignatov, A., Mishchenko, M.I., Geogdzhayev, I.V., Tanré, D., Deuzé, J.L., Goloub, P., Nakajima, T., et al., 2004. Intercomparison of satellite retrieved aerosol optical depth over the ocean. Journal of the Atmospheric Sciences 61, 499-513.

Norman, M., Leck, C., Rodhe, H., 2003. Differences across the ITCZ in the chemical characteristics of the Indian Ocean MBL aerosol during INDOEX. Atmospheric Chemistry and Physics 3, 563-579.

O'Dowd, C.D., de Leeuw, G., 2007. Marine aerosol production: a review of the current knowledge. Phil. Trans. Roy. Soc. A 365, 1753-1774.

O’Dowd, C.D., Smith, M.H., Consterdine, I.E., Lowe, J.A., 1997. Marine aerosol, sea-salt, and the marine sulphur cycle: A short review. Atmospheric Environment 31, 73-80.

O’Neil, N.T., Ignatov, A., Holben, B.N., Eck, T.F., 2000. The lognormal distribution as a reference for reporting aerosol optical depth statistics; Empirical tests using multi-year, multi-site AERONET Sunphotometer data. Geophysical Research Letters 27, 3333-3336.

Ovadnevaite, J., de Leeuw, G., Ceburnis, D., Monahan, C., Partanen, A.I., Korhonen, H., O'Dowd, C.D., et al., 2014. A sea spray aerosol flux parameterization encapsulating wave state. Atmospheric Chemistry and Physics 14, 1837.

Pant, V., Deshpande, C.G., Kamra, A.K., 2009. The concentration and number size distribution measurements of the Marine Boundary Layer aerosols over the Indian Ocean. Atmospheric Research 92, 381-393.

Prospero, J.M., Ginoux, P., Torres, O., Nicholson, S.E., Gill, T.E., 2002. Environmental characterization of global sources of atmospheric soil dust identified with the Nimbus 7 Total Ozone Mapping Spectrometer (TOMS) absorbing aerosol product. Reviews of geophysics 40 .

Rajeev, K., Ramanathan, V., Meywerk, J., 2000. Regional aerosol distribution 
and its long-range transport over the Indian Ocean. Journal of Geophysical Research: Atmospheres 105, 2029-2043.

Rasch, P.J., Collins, W.D., Eaton, B.E., 2001. Understanding the Indian Ocean Experiment (INDOEX) aerosol distributions with an aerosol assimilation. Journal of Geophysical Research: Atmospheres 106, 7337-7355.

Reddy, M.S., Boucher, O., Venkataraman, C., Verma, S., Léon, J.F., Bellouin, N., Pham, M., 2004. General circulation model estimates of aerosol transport and radiative forcing during the Indian Ocean Experiment. Journal of Geophysical Research: Atmospheres 109.

Sauvageot, H., 1994. The probability density function of rain rate and the

n estimation of rainfall by area integrals. J. Appl. Meteor. , 1255-1262doi 10. 1175/1520-0450(1994)033<1255:TPDFOR>2.0.CO;2.

Sauvageot, H., Lacaux, J.P., 1995. The shape of averaged drop size distributions.

口 J. Atmos. Sc. 52, 1070-1083. doi 10.1175/1520-0469(1995)052<1070: TSOADS $>2.0 . \mathrm{CO} ; 2$.

Schulz, M., de Leeuw, G., Balkanski, Y., 2004. Sea-salt aerosol source functions and emissions. Emission of atmospheric trace compounds 18 .

Sharqawy, M.H., Lienhard, J.H., Syed, M.Z., 2010. Thermophysical properties of seawater: a review of existing correlations and data. Desalination and Water Treatment 16, 354-380. doi:10.5004/dwt.2010.1079.

Smirnov, A., Holben, B.N., Kaufman, Y.J., Dubovik, O., Eck, T.F., Slutsker, I., Pietras, C., Halthore, R.N., 2002. Optical properties of atmospheric aerosol in maritime environments. Journal of the Atmospheric Sciences 59, 501-523.

Smirnov, A., Holben, B.N., Slutsker, I., Giles, D.M., McClain, C.R., Eck, T.F., Sakerin, S.M., Macke, A., Croot, P., Zibordi, G., et al., 2009. Maritime aerosol network as a component of aerosol robotic network. Journal of Geophysical Research: Atmospheres 114.

Soden, B.J., Bretherton, F.P., 1993. Upper Tropospheric Relative Humidity from the GOES 6.7 $\mu \mathrm{m}$ Channel: Method and Climatology for July 1987. J. Geophys. Res.-Atmos. 98, 16669-16688. doi:10.1029/93JD01283. 
Tian, B., Waliser, D.E., Kahn, R.A., Li, Q., Yung, Y.L., Tyranowski, T., Geogdzhayev, I.V., Mishchenko, M.I., Torres, O., Smirnov, A., 2008. Does the Madden-Julian Oscillation influence aerosol variability? Journal of Geophysical Research: Atmospheres 113.

Welton, E.J., Voss, K.J., Quinn, P.K., Flatau, P.J., Markowicz, K., Campbell, J.R., Spinhirne, J.D., Gordon, H.R., Johnson, J.E., 2002. Measurements of aerosol vertical profiles and optical properties during INDOEX 1999 using micropulse lidars. Journal of Geophysical Research: Atmospheres 107, 8019.

Wheeler, M.C., Hendon, H.H., 2004. An All-Season Real-Time Multivariate MJO Index: Development of an Index for Monitoring and Prediction. Monthly

a Weather Review 132, 1917-1932. doi 10.1175/1520-0493(2004)132<1917: AARMMI $>2.0 . \mathrm{CO} ; 2$.

Wheeler, M.C., McBride, J.L., 2005. Australian-Indonesian monsoon. Intraseasonal variability in the atmosphere-ocean climate system , 125-173.

${ }_{950}$ Winker, D.M., Pelon, J., Coakley Jr, J.A., Ackerman, S.A., Charlson, R.J., Colarco, P.R., Flamant, P., Fu, Q., Hoff, R.M., Kittaka, C., et al., 2010. The CALIPSO mission: A global 3D view of aerosols and clouds. Bulletin of the American Meteorological Society 91, 1211-1229.

Woodcock, A.H., 1948. Note concerning human respiratory irritation associated with high concentrations of plankton and mass mortality of marine organisms. J Mar Res 7, 56-62.

Yang, H., Pierrehumbert, R.T., 1994. Production of Dry Air by Isentropic Mixing. J. Atmos. Sci. 51, 3437-3454.

Yu, H., Kaufman, Y.J., Chin, M., Feingold, G., Remer, L.A., Anderson, T.L., Balkanski, Y., Bellouin, N., Boucher, O., Christopher, S., et al., 2006. A review of measurement-based assessments of the aerosol direct radiative effect and forcing. Atmospheric Chemistry and Physics 6, 613-666. 